\title{
NOTA SOBRE EL ARCHIVO DE LA FAMILIA PARDO GIL-TABOADA
}

\author{
MARÍA ROSA SAURÍN DE LA IGLESIA
}

\begin{abstract}
Resumen
La donación del archivo Pardo Gil-Taboada al del Reino de Galicia requería establecer la genealogía de quienes originaron tales documentos. Estos apuntes intentan trazar el perfil de una familia hidalga desde que empezó a dejar señales de su existencia hasta bien entrado el siglo XX. Superar la simple enumeración de personas - "como si la nobleza no hubiera tenido más función que la reproductora”, en palabras de Domínguez Ortiz - suponía añadir indicaciones sobre comportamientos individuales y tendencias colectivas del grupo familiar y eso es lo que se ofrece aquí sinteticamente, como una guía de urgencia que anuncie a futuros investigadores lo que podrán hallar en esta documentación: datos sobre la formación de un patrimonio familiar y sobre los criterios de administrarlo, sobre el papel de las mujeres en la acumulación de bienes, actitudes ante la vida, participación de la hidalguía en el crecimiento económico de Galicia y muchos otros aspectos que interesan tanto al historiador de la sociedad como al de la economía.
\end{abstract}

\section{Palaras clave}

Genealogía, Galicia, Hidalguía.

\section{Abstract}

The intention of the bequest of the archives of Pardo Gil-Taboada to the Archive of the Kingdom of Galicia was that of establishing the genealogy of those who were the original source of such document. These notes attempt to sketch the profile of a noble family from they left the first traces of their existence, to well into the XX century. Going beyond the simple enumeration of individuals - "as if the nobility had no other function than the reproductive" - requires the addition of evidence about the way individuals behaved and collective traits and predispositions of the family group. Hence it is hoped that in future researchs this guide will facilitate and provide data about the formation of a family heritage and criteria on its administration, on the role played by women in the accumulation of wealth, attitudes towards life and the participacion by the nobility in the economic development of Galicia, and other aspects which may be of interest to both historians of sociology and economics.

\section{Keywords}

Genealogy, Galicia, Nobility. 
Esbozar la historia de una familia es empresa a la que no debieran atreverse los inexpertos en materia tan escurridiza como la genealógica pero resulta indispensable para contextualizar la reciente donación al Archivo del Reino de Galicia de los papeles de Antonio Pardo Suárez y Juana Gil Taboada ${ }^{1}$. Se trata de un conjunto documental que va de los siglos XVII al XX, intacto hasta principios de éste en que se desgajó sin criterio claro entre Milagros e Inocencia Pardo Gil-Taboada, dos de las hijas de ese matrimonio. Los respectivos herederos de ambas decidieron ahora reunificar el conjunto y, dado su intrínseco interés, entregarlo a la prestigiosa institución encargada de conservar la historia del Antiguo Reino de Galicia. Queda así este corpus a salvo de contingencias como las que padeció al dejar de tener valor en vivo, como prueba irrefutable de un patrimonio cuyas rentas aseguraban la existencia a sus poseedores. Salvado de milagro tras quedar arrinconado en un desván (donde, en los años miserables de la postguerra, una persona de servicio merodeaba en busca de papeles que vender al peso) cumple ahora registrar lo que se sabe de sus poseedores, desenmarañando la tupida red de personas que le dieron vida y trazando una primera pista a seguir por eventuales estudiosos de la sociedad gallega. La enumeración afecta sólo a la línea principal, aunque sean igualmente interesantes las colaterales - los Parga, Pardo de Cela, Andrade, Vázquez da Fraga, Paz, Cao y Cordido, Romay, Maldonado, Leis, Luna, de Prado, Montenegro, Varela Reymondez, Figueroa, etc, etc -, cuya simple explanación excedería el propósito de este guión. Todos ellos contribuyeron a consolidar el patrimonio que permitió afirmarse a esta rama coruñesa. Sin la menor pretensión de exhaustividad, he aquí pues una minúscula pieza del gran mosaico que es la Historia de España. Y, si bien en formato reducido, aspira a ilustrar algo más que la simple capacidad de reproducirse de una familia. Estos documentos muestran la actitud autoprotectiva de la hidalguía gallega basada en la constitución de un sólido patrimonio territorial y financiero para, desde esa originaria acumulación de propiedades rurales, pasar a autoerigirse en grupo dirigente local haciéndose con el control del poder económico, ocupando el aparato administrativo y judicial - primero de la jurisdicción señorial y luego del Estado -, introduciéndose en la organización eclesiástica, ejerciendo cargos militares y trasladándose al fin a las Indias con parecidas funciones de gobierno. Cuando ya no queda en la Península descendencia por línea de varón de los Pardo ni de lo Gil Taboada, unos y otros la dejaron en cambio en la América

\footnotetext{
${ }^{1}$ Los donantes, poseedores hasta hoy de los papeles, son:

- María Teresa Pardo Rivas (29.VI.1924), casada, con descendencia;

- María de los Milagros Saurin de la Iglesia (19.VI.1930), casada, con descendencia;

- María Rosa Saurin de la Iglesia (20.V.1934), soltera; y

- Joaquin Saurin de la Iglesia (10.II.1937), casado, con descendencia.
} 
hispánica, donde arraigaron como oficiales del Rey o, al cambiarse las tornas y emanciparse los antiguos virreinatos, como simples emigrantes, según la próspera $\mathrm{o}$ adversa fortuna del momento.

Resulta difícil, al remontarse hacia atrás a través de los siglos, establecer a ciencia cierta el modo de transmisión de los apellidos o el por qué de combinaciones como la unión de Pardo con Cela, de Pardo con Andrade o de Gil con Taboada, que aparecen y desaparecen a gusto de los usuarios. Lo arbitrario o incoherente de ese uso, común en el pasado, complica la investigación, lo mismo que los repetidos matrimonios, cuyos hijos escogían diferentes posibilidades de identificarse. Y cuando la repetición a lo largo de generaciones de nombres de pila y apellidos se presta ya de suyo a error, la confusión se agrava por la costumbre de ciertos genealogistas de no aportar datos cronológicos o de silenciar a los segundones, con lo que las ramificaciones secundarias tienden a diluirse en la nada. Deploraba ya Federico Maciñeira en sus averiguaciones sobre el apellido Pardo Bazán no poder afirmar "si los [Pardo] de Lama procedían de los de Cela o si por afecto, vanidad u otra causa, basándose en imaginarios y lejanos parentescos, adoptaron el apelativo de éstos"2. Que eso databa de tiempo inmemorial lo confirma Vasco da Ponte, para quien era tal la multitud de los de ese nombre que acudieron a poner cerco a Pontevedra, deudos unos o simplemente adictos otros al Mariscal Pardo de Cela, que "con todos los Pardos y Rivadeneyras hacían poco menos que la mitad de Galicia"3.

Otras complicaciones derivan de la posibilidad de heredar el apellido por vía femenina, de lo que hay ejemplos en los albores de la Galicia moderna: primero y principal el caso de la Condesa de Lemos Doña Beatriz de Castro, de cuyo matrimonio con Don Dinis de Portugal en 1516 nació el primogénito Don Pedro de Castro y Portugal; y al casarse de nuevo la Condesa en 1521 con su primo Álvaro Osorio, el hijo de ambos se llamó Don Rodrigo de Castro Osorio ${ }^{4}$. Más próxima a nuestro caso es la condición impuesta por el fundador del mayorazgo de Liñares en 7 de junio de 1625 de "que el varón o enbra que suscediere en este mayorazgo y marido que con ella casare tome el apellido principal de los tavoadas y pongan las armas de mi linaje questan en mis casas en los escudos de armas ..." ${ }^{5}$. A ese comportamiento se ajustan los Pardo y los Gil Taboada. Una llamativa endogamia engarza a todos en un sistema de parentesco cristalizado en una eficaz red de poder. El recí-

\footnotetext{
${ }^{2}$ F. G. MACIÑEIRA, "Genealogías gallegas. La de Emilia Pardo Bazán”, Almanaque Gallego para el año 1904, Ortega y Radaelli, Buenos Aires, 1903, pp. 70-79.

${ }^{3}$ Ibid.

${ }^{4}$ Gran Enciclopedia Gallega, S. Cañada, Santiago, 1974, 19, p. 31.

${ }^{5}$ C. GÓMEZ BUXÁN, "As armas dos Taboada. Aproximación a unha peculiaridade heráldica dezá", $C E G$, n $^{\circ} 118$, LII, 2005, p. 403.
} 
proco apoyo entre consanguíneos puede rastrearse ya desde la pila bautismal, donde los apellidos de los padrinos suelen prefigurar futuras alianzas matrimoniales para el recién nacido. Ese constante referencia a un círculo estricto de parientes y valedores remacha una solidaridad familiar que, en ocasiones, linda con lo político: tal sucede cuando los miembros del grupo se van implicando progresivamente en servicios que contribuyen al mantenimiento del Estado, y no sólo dentro de la Península. Así lo refleja la mención hecha en el cursus honorum de cada miembro de los méritos de antepasados que habían ejercido cargos institucionales, garantía de la fidelidad de sus sucesores a tan altos ejemplos.

Los Pardo, una vez preteridos los oficios municipales que habían ejercido en el siglo XVI, permanecieron más vinculados a sus raíces rurales alternando el cuidado de sus tierras, fuente de ingresos primordial, con la práctica de profesiones liberales, sin desdeñar otras rentables ocupaciones, desde el arriendo de diezmos hasta el préstamo de cereales, ineludible servicio de los ricos en una sociedad rural desprovista de instituciones de crédito. Redondeaban así una hacienda desequilibrada por la numerosa prole y no se desdoraban por participar en sociedades mercantiles de España o las Indias. Llegada la hora de la Desamortización tampoco dudaron en adquirir bienes nacionales para acrecentar el patrimonio familiar, sin arredrarse ante las condenas de la Iglesia. Al decaer el talante guerrero de la nobleza forjado en el Medioevo, alguno de los requeridos en la última fase de las guerras con Portugal para defender Porriño, Vigo y Tuy, se eximía pretextando hallarse "pobre y sin armas i cavallo y sin poderse sustentar en la guerra privado de la vista y quebrado, por lo que pidió le visitase un Ziruxano"'6. Pero las armas, entendidas según el moderno concepto de carrera al servicio del Estado, siguieron atrayendo a varios miembros de la familia.

Trazar un perfil del linaje a otro nivel requeriría reconstruir sus ideas o gustos culturales. La titulación académica de algunos - Licenciados en Teología y Leyes, graduados en Cirujía - no certifica que, salvo excepciones, la familia brillara por doctrina o amor a las letras pero la performance de $\mathrm{Sada}^{7}$, elaborada con arreglo a rituales académicos consolidados, hace pensar en un puntual conocimiento de costumbres universitarias. No sobreviven otros libros que la Resumpta Historia de España, desde el diluvio hasta el año de 1642. Compuesta por el Licenciado Francisco de Cepeda, natural de Oropesa (Madrid, Diego Díaz La Carrera, 1654), muy manoseada, muy leída, con la firma de Gonzalo Gil de Taboada. La elección, en

\footnotetext{
${ }^{6}$ A. DOMÍNGUEZ ORTIZ, "La nobleza como estamento y grupo social en el siglo XVII", Nobleza y sociedad en la España moderna, Ed. Nobel, 1996, p. 129, ID., Las clases privilegiadas en la España del Antiguo Régimen, Istmo, Madrid, 1973, p. 138.

${ }^{7}$ Apéndice $n^{\circ} 3$.
} 
otra rama de los Gil Taboada, de onomásticos como Galaor, Briolanja o Leonel revela un gusto arcaizante por aquella "materia de Bretaña" que chifló a Don Quijote, pero en ésta la aquiescencia al santoral acredita prácticas religiosas corrientes, igual que los cuadros y objetos religiosos enumerados en los testamentos. Las mujeres no solían saber escribir pero aportaron consistentes bienes.

Como era de rigor en este escalón inferior de la nobleza, nadie hace uso del Don hasta bien estrado el siglo XVIII, a menos que lo respaldase la posesión de un título académico. Uno de los valores convencionales de la época, el orgullo del linaje, es sostenido a toda costa, incluso despreciando la moralidad convencional ${ }^{8}$; orgullo a veces rayano en la proverbial insolencia de los señores, delatada en la tensa relación vecinal, en denuncias ante los tribunales: si los señores se propasan a injurias de "palabras mayores", los ofendidos se vengan con agresiones, incluso emplazando una horca simbólica en terrenos del adversario; orgullo que perpetúa la sangre fundando vínculos y mayorazgos y que recurre para justificar sus orígenes al mito, entreverando con lo verídico la faramalla fabulosa de los Reyes de Armas. Si la casa solariega representó durante siglos la concreción de riqueza y poder, no fue esta familia la llamada a conservar una y otro, por más que en San Julián de Soñeiro exista aún la casa de los Pardo (propiedad de María de la Concepción Álvarez Pardo), ya alterada en estructura y aspecto. A poca distancia se hallaba hasta fines del siglo XIX la Casa grande dos Xil o Casa do Monte, hoy enteramente arruinada: todo un símbolo del desmoronamiento

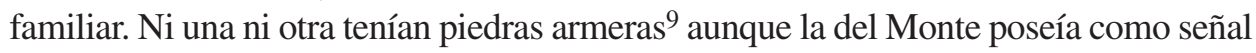
inequívoca de la hidalguía de sus propietarios el oratorio concedido por Clemente XIII, en buleto sellado y firmado el 7 de septiembre de 1765 por el Cardenal Rezzonico.

\section{LOS PARDO}

A. Gonzalo da Rigueira el viejo, casado con Sancha Oanes, produjo información de nobleza en 1604. Era tenido entre sus vecinos por hijodalgo notorio y descendiente de tales. Hijo suyo fue

\footnotetext{
${ }^{8}$ Leonel Gil Taboada y Camba, cura de Santa Mariña de Ribela, asegura el futuro de sus propios hijos despreciando todas las leyes habidas y por haber, vinculando a su favor grandes propiedades, dando estudios al varón en Salamanca y concertando ventajosos matrimonios para las hijas: v. AHRG, Ejecutorias, leg. 7152-28, con sabrosos datos sobre la dolce vita estudiantil compostelana a mediados del siglo XVII. Sobre los problemas de D. Leonel con sus feligreses v. AHRG, Particulares, leg. 4113-24 y leg. 4113-42

${ }^{9}$ Sobre el derecho a exhibirlas v. Apéndice $\mathrm{n}^{\circ} 1$. Sobre la pervivencia de los símbolos propios de los Gil Taboada cfr. E. PARDO DE GUEVARA Y VALDÉS, Palos, fajas y jaqueles. La fusión de armerías en Galicia durante los siglos XIII al XVI, Diputación Provincial, Lugo, 1997, pp. 73-86.
} 
B. Fernando Migues da Rigueira, casado con María Sánchez de Freixomil, que vivían en la Casa del Busto, Santa María de Fisteus. Fueron padres de

C. Gonzalo da Rigueira Freixomil, casado con Inés López. Como en 1622, según el párroco D. Jacinto Bañales y Moscoso, "en su iglesia no tenía libros antiguos de Bautizados ni Difuntos" por haberse perdido, recurrió al testimonio público para certificar que no pechaba como plebeyo. Tuvieron por hijo al

D. Capitán Juan da Rigueira Freixomil, casado con María Pardo de Cela. Hicieron testamento el 3.III.1659. Fueron sus hijos:

1. El Alférez Jacinto Tomé Pardo, casado con Isabel Sánchez, hija del Comisario Pedro Sánchez de Parga, de Santa María de Ois. Fue hijo suyo Gregorio Antonio Pardo, bautizado el 24.III.1662 en la misma parroquia siendo padrinos el Capitán Jerónimo de Parga y su mujer Magdalena de Gayoso y Luaces. Obtuvo en 1744 ejecutoria de hidalguía de la Chancillería de Vallado$\operatorname{lid}^{10}$. Del matrimonio de este Gregorio Antonio ${ }^{11}$ y María da Ponte y Andrade fue hijo Antonio Pardo da Ponte casado con María da Roca;

2. Gonzalo da Rigueira;

3. Inés Pardo, casada con Pedro da Espiñeira;

4. Basco Pardo;

5. Pedro Pardo;

6. Bernardo da Rigueira; y

7. Antonio Pardo da Rigueira, que sigue.

E. Antonio Pardo da Rigueira, casado en primeras nupcias con María López de Morandeira, hizo testamento el 16.IV.1695, y tuvo por hijos a

1. Domingo Antonio Pardo de Andrade y Rigueira, vecino de Santiago; y

2. Blas Pardo de Andrade y Rigueira.

Estos dos hermanos y su primo Gregorio Antonio Pardo exhibieron documentos fehacientes de su hidalguía para que "los coxedores del coto" los eximiesen de compartos y repartimientos. Y como unas veces los eximían y otras no,

${ }^{10}$ Lo confirma P. PÉREZ COSTANTI, "Linajes galicianos", $B R A G$, t. 7, no 75, 1913, p. 82. e

${ }^{11}$ Cfr. C. MARTÍNEZ BARBEITO, Torres, pazos y linajes de la provincia de La Coruña, Diputación Provincial de La Coruña, 1986, p. 262: al describir el pazo do Fachal, en tierra de Curtis, da por extinguida la familia tras un hijo de Gregorio llamado Juan Pardo Freixomil y Moscoso y eel nieto Ignacio Pardo Freixomil. Muy al contrario, los papeles Pardo Gil-Taboada acreditan la continuidad de la estirpe por otros caminos. 
acudieron a Francisco Caneiro de Arriola "escrivano mayor y más antiguo de Betanzos", quien a través de los libros de acuerdos del Ayuntamiento demostró que el 6.I.1716 se había nombrado "por alcaldes hixos dalgo por dicha ciudad a Don Pedro Pardo de Zela y Andrade hixo lexitimo de Don Juan Pardo de Zela y Doña Andrea Pardo", deudos de los solicitantes. Con ello lograron que "la Justicia concexo vecinos y empadronadores de la feligresía de Santa María de Fisteus les pongan y anoten en el Padrón executado en ella el año pasado de setecientos y treinta y siete de horden de la Sala por hixos dalgo y les tilden y vorren las partidas que en el les pusieron de Pecheros y en su consequencia por ahora y sin perxuicio del real Patrimonio les guarden todas las honrras exemciones franquezas y libertades que les corresponde como a tales hixos dalgo y si por razon de pechos de Pecheros les hubiesen sacado algunas prendas o Marabedis se las buelban y restituian libremente y sin costa alguna ...”.

En segundas nupcias Antonio Pardo da Rigueira casó con Catalina González de Moscoso, y con ella hizo testamento el 16.IV.1695 estando en sus casas del Busto. De este segundo matrimonio fueron hijos:

3. Francisco Pardo de Andrade y Rigueira; y

4. Bernardo Pardo de Andrade Rigueira y Freixomil, que sigue.

F. Bernardo Pardo de Andrade Rigueira y Freixomil, nacido en Santa María de Fisteus, casó en primeras nupcias con Mariana Sánchez de Lamas. Del segundo matrimonio con Margarita Varela de Seixas tuvo a

1. Francisco Pardo da Rigueira, nacido el 19.VIII.1725; luego vecino de Santa María de Foxado, y

2. Andrés Domingo Pardo de Andrade y Rigueira, que sigue.

G. Andrés Domingo Pardo de Andrade y Rigueira (23.I.1731, Santa María de Fisteus), dueño del vínculo fundado por el hidalgo de Soñeiro Juan Antonio de Luna y Sarmiento. Casó en 2.II.1769 con María Elena Gómez da Fraga y Patiño, hija ésta de José Antonio Vázquez da Fraga y Caamaño el mayor, definido así en el Catastro de Ensenada: "Partero, flebotomista, casado, su hedad 44 años, tiene cinco hijos menores, con dos empleados en estudios menores y maiores, dos hijas y una criada. Se le regula por tal flebotomista al año en quatrocientos Rs. y trescientos por arrendatario de los efectos diezmales". La solvencia económica era el primer requisito para ello ${ }^{12}$.

12 Otro hidalgo se ocupaba de iguales menesteres en el inmediato Xaz, D. Manuel Pardo de Andrade, padre del famoso escritor: v. M. R. SAURÍN DE LA IGLESIA, Manuel Pardo de Andrade y la crisis de la Ilustración, Gaesa, La Coruña, 1991, pp. 5-6. 
En esa familia hubo escribanos de S. M., como Alonso Vázquez da Fraga, y presbíteros como el Licenciado Pedro da Fraga, que testó en 1700. El cirujano Fraga, casado con María Antonia Gómez Patiño el 28.III.1734, tuvo estos hijos:

- Manuel, capellán del Batallón Santa Fe, muerto en Caracas en 1795;

- Francisco, nacido el 2.IV.1737;

- Juan, cirujano titulado en el Real Protomedicato de Santiago, casado con Josefa Vermudez del Valle (padres ambos de Francisca Vázquez da Fraga, esposa de Joseph Antonio Vidal, escribano de S. M. en Betanzos, que fue dueña hasta su muerte en 1850 del vínculo fundado por el Licenciado Isidro Chancela);

- Pedro, soltero, vecino de Caracas en 1797;

- María Elena, nacida el 16.II.1744;

- Manuela, casada con Julián Reymondez, vecinos de Osedo.

Al ir Andrés Domingo Pardo "a casar y avecindar a la feligresía de San Julián de Osedo" pidió que el concejo y vecinos "le den y señalen el estado que de Hijo Dalgo lexitimamente le corresponde, y sin embargo de constarles su notoria nobleza se han excusado". Obligado a hacer nueva información, afirmaba que tan molesta insistencia no tenía más objeto que "mortificar y hazer gastar y aun privar del ditado" de hidalgo a quienquiera que rechazase prestaciones propias de los plebeyos. Que las autoridades locales trataban por todos los medios de sacudirse a los no contribuyentes lo confirma una infinidad de casos semejantes ${ }^{13}$. Andrés Domingo acudió a la Chancillería de Valladolid alegando una vez más su condición de hidalgo de sangre notorio ${ }^{14}$. Y la Real Sala de Hijosdalgos atendió su petición despachando Real Carta Executoria fechada en 1775. Fueron sus hijos:

1. Juana Antonia (8.V.1770), casada con Francisco Fernández;

2. Manuela Francisca (15.II.1772); casada el 18.II.1803 con José Moscoso, de Santiago de Sigrás,;

3. José, que sigue;

4. Juana Ignacia (29.XI.1774), casada el 23.XI.1806 con Jorge Gonzalez, de San Jorge de Iñás;

5. Roque Antonio (16.VIII.1777), casado con Dorotea Otero. En 1805 era segundo jefe del primer trozo de la Jurisdicción de Miraflores; y en 22.IX.1811 solicitó plaza de Juez en los Estados del Conde de Lemos ${ }^{15}$.

${ }^{13}$ Cfr. A. DOMÍNGUEZ ORTIZ, Las clases privilegiadas en el Antiguo Régimen, Istmo, Madrid, 1973, pp. 35 y 138.

${ }^{14}$ AHRG, Protocolos, leg. 1593, f. 2: 26.III.1775

${ }^{15}$ AHRG, Causas, leg. 28-4; y AMC, Varios 1811,II. 
6. María Juana (3.VII.1779), que casó el 16.I.1790 con Amaro Conchado (1764, Sta. Maria de Cambre). Fue hija de ambos Andrea Conchado y Pardo, nacida en Soñeiro en 1792 y fallecida allí mismo el 14.V.1874, quee casaría con Gonzalo Gil Taboada y Gil Taboada el 30.VIII.1812;

7. Juan María Francisco (26.X.1781), casado en 1802 con María da Uz y Ortega; ese mismo año se tituló de cirujano en el Real Protomedicato de Santiago.

8. Manuel (1.V.1785)

7. Josefa Francisca (18.XI.1787).

H. José Pardo da Rigueira (6.VIII.1773, San Julián de Soñeiro - 28.IV.1855, San Nicolás de La Coruña). Vinculeiro del fundado por el Licenciado Chancela. Casó con Juana Suárez Sánchez (14.II.1860, San Jorge, La Coruña + Santiago, La Coruña). En 1808 eran vecinos de Santa Lucía. En el testamento ante Manuel de Agra en 20.XII.1839 afirman haber tenido once hijos "de los que existe en el día D. Antonio, de veintiseis años, soltero, pues los otros fallecieron en tierna edad". Los que llegaron a adultos eran:

1. Anselmo Benito que murió a los dieciocho años a bordo de la corbeta de Guerra de S. M. la Isabel en 15.X.1818, en viaje para Honduras;

2. Baldomero, "muerto a los quince años a bordo de una balandra, regresando de un viaje a la costa de Africa" el 5.I.1836, lo que confirma la participación de las mejores familias locales en el rentable tráfico de negros practicado por los armadores de La Coruña ${ }^{16} ;$ y

3. Antonio Francisco Pardo Suárez, que sigue.

I. Antonio Francisco Pardo Suárez (20.XII.1813, San Jorge, La Coruña 4.I.1876, Santiago, La Coruña). Casado el 21.VI.1847 en primeras nupcias con Ana Manuela Gil Taboada y Conchado (25.I.1813, San Julián de Soñeiro - 7.VII.1851, La Coruña) y el 11.III.1855 en segundas con la hermana menor de ésta, Juana María Teresa (24.X.1830 - 8.XI.1885). Hizo testamento el 2.I.1876 ante Francisco Ramos Vázquez. Antonio Francisco, notario y procurador de número de la Real Audiencia de Galicia ${ }^{17}$, vivía en la casa de la calle del Parrote ${ }^{\circ} 16$ de La Coruña - al lado de la Audiencia del Reino - donde nacieron casi todos sus hijos y continuaron sus descendientes hasta 1989. En algunas causas conservadas en el Archivo

${ }^{16}$ Cfr. L. ALONSO ÁLVAREZ, Comercio colonial y crisis del Antiguo Reino de galicia (17781818), Xunta de Galicia, La Coruña, 1986, pp. 223-234.

${ }^{17}$ AHRG, Real Audiencia, leg. 460/14 antiguo, 29007. 
del Reino queda constancia de su actuación como procurador que traslucen su ideología liberal. Fueron sus hijos:

1. Gonzalo José Antonio (27.V.1848, San Jorge de La Coruña - 6.VII.1930). Soltero, sordomudo de nacimiento, el juez le reconoció "capacidad para administrar sus bienes por saber leer, escribir y contar, educación que recibió en la Escuela de Sordomudos de Madrid donde estuvo el tiempo reglamentario". Pudo así viajar, solo, a Méjico y Cuba para cuidar intereses de familia. Frecuentó la Escuela de Artes y Oficios de La Coruña ${ }^{18}$, y de sus dotes dan fe los retratos de sus padres por él pintados así como la restauración de retablos e imágenes de varias iglesias de la comarca;

2. Ricardo Gonzalo Antonio (20.XII.1849, San Nicolás, La Coruña, murió de niño)

3. María del Socorro (21.VII.1856, murió de niña);

4. Luisa María Valeriana (14.IV.1857, San Nicolás, La Coruña - 3.I.1940), casada el 10.III.1873 con Ramón Marcelino María Tabares Berdiñas (4.VI.1837 - 25.II.1914), cuya ejecutoria de hidalguía portuguesa se conserva. El certificado de matrimonio civil, celebrado en plena República, sugiere preferencias ideológicas próximas a las del padre de la novia. Residieron en Guanajuato, Méjico, donde Tabares tenía negocios en compañía de sus hermanos;

5. Adolfo Joaquín (25.VIII.1858, Santiago, La Coruña, murió de niño);

6. Ricardo José Gonzalo (12.VIII.1859, Santiago, La Coruña); en 1875 se trasladó a La Habana; en 1891 vivía en Méjico, y en 1901 colaboraba con la sociedad constructora norteamericana Pearson \& Co. Casado con Mercedes Nemes.

7. Justo Joaquín Antonio (28.XI.1861-17.V.1935, Santiago, La Coruña). Se estableció en Méjico. Casado con María de la Concepción Manero Embides. De los cinco hijos que tuvieron, el único varón, Pedro, falleció en Nueva York donde estudiaba. Queda numerosa descendencia por línea femenina.

8. Graciano Joaquín (14.VI.1863, Santiago, La Coruña - 1927). Sordomudo de nacimiento, la opinión de su hermano Gonzalo pesó mucho en la decisión de no mandarlo a la Escuela de Sordomudos y, como no aprendió a hablar, toda la familia practicaba el lenguaje de los signos. Murió soltero;

9. María de los Milagros (Santiago, La Coruña, 27.X.1864 - 28.XI.1939), casada el 25.XII.1889 con Eugenio Alfredo de la Iglesia y Santos (19.X.1861-

${ }^{18}$ BOPC, 29.V.1868, Exámenes de fin de curso en la Escuela de Bellas Artes de La Coruña, 18671868. Dibujo de figura: Gonzalo Pardo y Gil, sobresaliente y premio; Román Navarro sobresaliente y mención honorífica. 
17.V.1933), director del Colegio General y Tácnico de Ferrol hasta 1917 en que pasó a Pontevedra como catedrático de Literatura del Instituto. Tuvieron por hijos a Jaime, María de la Concepción, Eugenia, Carmela e Isabel. Carmela de la Iglesia Pardo (16.VII.1897 - 16.IV.1989) casó el 9.IX.1922 con Joaquín Saurin Signo (9.IV.1886 - 10.I.1959) y fueron sus hijos: Carmela (6.VIII.1923 - 19.X.1979), Margarita María del Pilar (18.IX.1925 23.XI.1983), María de los Milagros Eugenia (19.VI.1930), María Rosa Sara (20.V.1934) y Joaquín Angel Alfredo (10.II.1937)

10. Adolfo Segundo Francisco Antonio (28.IX.1866, Santiago, La Coruña). Casó con Dolores Pan en primeras nupcias y con Elvira Eiroa en segundas;

11. Andrés Manuel, que sigue;

12. Roberto José Antonio (26.XII.1869, Santiago, La Coruña); en 1891 era vecino de Buenos Aires y se dedicaba al comercio. Allí se casó dejando descendencia femenina.

13. Angel (12.VI.1871, Santiago, La Coruña; murió de niño);

14. Inocencia (18.XII.1874, Santiago, La Coruña, inscrita en el Registro civil el 31 de diciembre-julio 1962), soltera.

J. Andrés Manuel Pardo Giltaboada, (11.VIII.1868, Santiago, La Coruña 23.IV.1924), casado con Micaela Hidalgo Hervada (7.V.1868, Tamarite de Campos - 17.III.1944), tuvo por hijos a

1. Andrés Pardo Hidalgo (26.VII.1890 - 18.II.1872), casado el 12.I.1912 con María de la Concepción Rivas Rey (2.X.1893-30.III.1976). Fueron sus hijos: - María de la Concepción (25.IV.1913 - 14.IV.2001), casada, con sucesión;

- Andrés (20.VI.1919; murió de niño);

- María Teresa (29.VI.1924), casada, con sucesión.

2. Gonzalo (28.X.1894-19703), casado, con sucesión; y

3. María de los Angeles (14.IX.1891- febrero 1975) casada, con sucesión ${ }^{19}$.

\footnotetext{
${ }^{19}$ Otros datos sobre los Pardo en archivos locales: CNC, 15.II.1774, Antonio Pardo da Rigueira como apoderado de F. A. Patiño (J. A. García y Gómez, Prot. 73, f. 23); CNC, 24.VIII.1778, venta de A. D. Pardo da Rigueira (Vázquez Varela, Prot. 5079-5080, f. 13); AHRG, Protocolos, leg. 1538, f. 64: el 28.VII.1776, el mismo curador ad litem; AHRG, Prot., leg. 1500), 9.III.1784, el mismo sobre cierre del monte del Espíritu Santo; AHRG, leg. 1537, f. 97: 13.VIII.1785, venta del mismo; CNC, Ver ${ }^{\circ}$ Ant ${ }^{\circ}$ Posse, Prot. 5262: 15.I.1791, venta del mismo; AHRG, Causas, leg. 28-41: 1805, el mismo sobre venganzas; AMC, 27.IX.1811, poder de Mauro Conchado; ibid., 25.IX.1811, poder de Roque Pardo y Regueira; AHRG, Protocolos, leg. 2075, f. 57: 5.XII.1820, venta de Roque Pardo.
} 


\section{LOS GIL TABOADA}

Los orígenes de la familia Gil Taboada se encuentran en la tierra de Deza. Hay estudios recientes centrados en los Taboada $^{20}$ pero sin referencia alguna a la rama afincada en La Coruña desde el siglo XVII. Origen de ella ha de considerarse a

A. Cristóbal Gil Lameyro y su esposa Mencía López, vecinos de San Miguel de Bendoiro, de cuyo matrimonio quedaron los siguientes hijos:

1. Sebastián Gil Lameyro, labrador, vecino de Bendoiro;

2. Helena Frois, llamada otras veces Herena Gil o Elena Fernández, casada con Domingo de Vilariño, ambos vecinos de San Martiño de Prado, en tierra de Deza;

3. Isabel Gil, llamada a veces Isabel López, mujer de Pedro de Ermida, ya difunta en 1614 y de la que quedaban "dos o tres hijos, el uno de ellos se llama Xtobo y vive en La Coruña"; los otros eran Francisco, Alonso, Antonia y María Gil.

4. Gonzalo Gil, que en 1564 pleiteaba con el Conde de Monterrey sobre exención por hidalgo y "no deber pagar como los del estado llano tocinos y carneros por razón de señorío" 21 . Al morir en 1614, su "deudo mas propinquo" el Capitán Gómez Taboada, de San Martín de Callobre, pide recuento de bienes dando origen a un pleito que duraría cincuenta años con los hermanos legítimos del difunto ${ }^{22}$. Éste, vecino de Santiago, lugar de Pitelos, Santa María del Sar, tenía fama de ser "el mercader más caudaloso de esta ciudad". De su matrimonio con María Díaz había tenido un hijo, el canónigo de Santiago Domingo Gil Taboada, muerto ab intestato pocos días antes que su padre y de quien quedaba un hijo natural, Francisco Díaz Gil de Taboada. Al mes de morir Gonzalo fallecía también su esposa María Díaz, con testamento del 24.X.1614. Negocios y tren de vida de este hidalgo trasplantado del ambiente rural a la ciudad más opulenta del Reino brindan insólitos perfiles de su grupo social. La muerte lo había sorprendido en plena actividad, al

${ }^{20}$ C. de la PEÑA VIDAL, "Casa de Carballeda: los Gil Taboada de Trasdeza”, $D, \mathrm{n}^{\circ}$ 5, 2003, pp. 73 90; C. GÓMEZ BUXÁN, op. cit., pp. 390-426; C. de la PEÑA VIDAL, "Los Gil Taboada de Deza. Casas de Barcia, Bergazos y Des", D, 2004, n 6, pp. 11-40. Referencias a los Gil en M. de TOUBES, Tocante a los hijosdalgo, 3.VIII.1603, ed. de F. Rubia Alejos y C. Gómez Buján, D, 2000, nº 2, pp. 13-68.

${ }^{21}$ AHRG, Figueroa, leg. 1092/69.

${ }^{22}$ AHRG, Fariña, leg. 13267 n 35. 
regreso de un viaje en compañía del hijo canónigo, después de vender "acaso más de trescientas mulas pocos dias antes que se partiese a la jornada de Ribadavia". Gran dinamismo e iniciativa revelan sus variadas transacciones marítimas y terrestres, los tratos con navíos franceses en Sevilla y Padrón, el volumen y naturaleza de las mercaderías: barricas de vino, sardinas y lampreas, cargas de aceite y arrobas de azúcar embarcadas "en el navío la Flor de Lis, maestre Pedro Gareao" (y lises eran las armas de su pariente Jácome Froiz). $\mathrm{El}$ inventario de bienes ofrece una impresionante cantidad de inmuebles, cartas de pago, foros, depósitos y relaciones de prendas que remiten sin duda alguna a la práctica del préstamo. Es, en suma, la personificación de aquella "sociedad expansiva" que fue España antes de enquistarse en sí misma ${ }^{23}$. Los crismas del triunfador se concentran en nuestro hombre con detalles reveladores: pertenecía a las cofradías de Nuestra Señora la Antigua y de la Vera Cruz; su título de familiar del Santo Oficio firmado por el Señor Inquisidor Alonso Blanco y refrendado por el Secretario Baltasar Fernández de Isla le garantizaba prestigio social, tratamiento de favor e inmunidades económicas como la exención de mantener soldados y hombres de armas, la pronta resolución de casos controvertidos y la devolución de prendas ${ }^{24}$; promovía la ascensión futura de sus parientes asegurando estudios a los varones durante ocho años y a las hembras la permanencia en el monasterio de las Huérfanas en espera de contraer matrimonio ventajoso. Mobiliario y ropa suntuosos, manteles "alemaniscos", ochenta y dos pares de calzas, joyas de oro y coral, vajillas, cuberterías de plata confirman su privilegiado status social. Dispuso ser sepultado junto con su hijo el canónigo en la iglesia de San Miguel de Bendoyro. La decisión de encomendar la testamentaría a varios parientes próximos revela la solidaridad entre miembros del linaje. Como apoderados figuran Vasco Taboada do Carrio y Pedro Fernández Gil de Noguerol, escribano de S. M., de Santa María de Don Ramiro 25 ; y como curadores de los herederos menores, Gonzalo Taboada, Pedro Taboada y Gregorio Gil: toda una red de autoprotección constituida por un entorno familiar de eficientes burócratas al ser-

${ }^{23}$ Cfr. J. A. MARAVALL, "La imagen de la sociedad expansiva en la conciencia castellana del siglo XVI", Mélanges en l'honneur de Fernand Braudel, Privat, Tolouse, 1973, I, pp. 369-388.

${ }^{24}$ J. CONTRERAS, El Santo Oficio de la Inquisición en Galicia (Poder, sociedad y cultura), Akal, Madrid, 1982, pp. 103-110; v. también P. MOLAS, La burguesía mercantil en la España del Antiguo Régimen, Cátedra, Madrid, 1985, especialmente el Apéndice Comerciantes y familiares de la Inquisición en Cataluña en el siglo XVIII.

${ }^{25}$ Sobre este personaje, vecino de Santiago en 1705 y contador del Santo Oficio de la Inquisición en el Reino de Galicia v. C. GÓMEZ BUXÁN, "Xenealoxías dezanas”, D, 2003, n 5, pp. 15-16. 
vicio del Conde de Lemos. Se dibuja así un elemento tan importante en el afianzamiento del clan como es la endogamia. Decisivo para ese engrandecimiento fue el paso del ámbito rural originario al más vasto círculo compostelano y, al fin, a la cosmopolita Coruña. Teniendo en cuenta que varios miembros de la familia pertenecían ya en el siglo XVI a la burocracia señorial de la Casa de Lemos no extrañaría que el traslado a La Coruña de algunos de sus sucesores se hubiera producido al hilo del nombramiento del Conde de Lemos como Alguacil Mayor del primer Tribunal del Reino en 1717.

B. Cristóbal Gil Taboada fue hijo de Isabel Gil Taboada y Pedro da Ermida, aunque "parece que"26 hubo un Cristóbal Gil Taboada, hijo de Jorge Gil Taboada, de la casa de Bergazos, y hermano por consiguiente de Pedro y de Gómez Gil Taboada, heredero éste de ella. Sea como fuere, en 1641 tenía cincuenta años, era vecino de Santiago y familiar del Santo Oficio ${ }^{27}$. El 27 de abril de 1655 consta como mercader en la misma ciudad. A su munificencia se debía "el lumbre de la cofradía del glorioso San Antonio" de la Catedral, donde también fundó dos capellanías. En 1659 estaba casado con Elena Vallo de Porras, viuda de Benito López de Bendaña Fociños, escribano que había sido de la Audiencia arzobispal de Santiago ${ }^{28}$.

De matrimonio anterior con María de Fontao era hijo

C. Jacobo Gil Taboada, Doctor en Leyes, abogado de la Real Audiencia y tesorero de la Universidad. En 1655 dedicaba un altar a Nuestra Señora del Buen Suceso en la iglesia de Santo Domingo de Santiago, con sepultura para sus padres Cristóbal Gil Taboada y Maria de Fontao, fallecida probablemente ese año ${ }^{29}$. En 1672 se declaraba "unico heredero de Xtobo Gil su padre". De su matrimonio con María Luisa da Pedreyra Gago y Losada tuvo por hijos a:

1. Bernardo Gil Taboada da Pedreyra Losada, Licenciado y en 1692 cura propio del beneficio de Santa María de Bean ${ }^{30}$, "hijo de D. Jacobo Gil Taboada, difunto, y Da María Luysa da Pedreyra Gago y Losada, que oy vive" y nieto de D. Cristóbal Gil Taboada ${ }^{31}$;

${ }^{26}$ Así, sin más, J. S. CRESPO, Blasones y linajes de Galicia, Ed. Boreal, La Coruña, 1997, II, p. 311.

${ }^{27}$ CONTRERAS, op. cit., p. 171.

${ }^{28}$ AHRG, Fariña, leg. 13268/49.

${ }^{29}$ Cfr. Fr. A. PARDO, "La iglesia de Santo Domingo de Santiago. Capillas subsistentes y desaparecidas", CEG, III, 1945, pp. 398-399.

${ }^{30}$ AHRG, Fuerzas eclesiásticas, leg. 27056-162 y 27038-38.

${ }^{31}$ AHRG, Fuerzas eclesiásticas, ibid. y leg. 27062-235. 
2. Fr. Manuel Gil Taboada, franciscano en 1688;

3. Fr. Joseph Antonio Gil Taboada, en 1684 novicio en San Francisco de Santiago y luego Lector de Artes en San Francisco de Salamanca. En 15.VIII.1708 era Lector de Teología en San Lorenzo de Trasoutos de Santiago ${ }^{32}$. Su fama literaria, confirmada por diferentes obras publicadas e inéditas, se conserva hoy por sus poesías en gallego en las Fiestas Minervales de 1697 de la Universidad compostelana en honor de Fonseca. Murió en Salamanca el 26.IV.1716 33 ;

4. Josefa Bernarda; y

5. María Rosa Taboada, ambas "donzellas menores, recogidas en el Convento de Santa María de Belbís extramuros de Santiago". El 6 de agosto de 1732 Sor María Rosa Gil Taboada era abadesa de Santa Bárbara de La Coruña ${ }^{34}$. Jacobo Gil Taboada murió en 1688 y su viuda $\mathrm{M}^{\mathrm{a}}$ Luisa da Pedreira Losada casó en segundas nupcias con Pedro Fernández Noguerol ${ }^{35}$.

De otro matrimonio fue hijo Jacobo Gil Martines de Taboada, que sigue.

D. Jacobo Gil Martines de Taboada, en 1672 era vecino de La Coruña. Casó con Maria Xuares da Pedreyra y Bergondo, por cuyos bienes en las feligresías de Carnoedo y Osedo pleitea en $1679^{36}$. En 2.VII.1712 firma la carta de dote de su hija Isabel María. En 1721 vivía en la Casa y lugar das Mantas, San Andrés de Carnoedo, que le fue vendida de orden judicial por impago de deudas referidas a barricas de vino (lo que sugiere actividades mercantiles como las de sus antepasados). En 1722 era vecino de La Coruña. Entre sus hijos se cuentan:

1. José Antonio Gil Martínez Taboada da Pedreira, que sigue;

\footnotetext{
32 Cfr. Fr. A. PARDO, "Convento de San Lorenzo de Trasoutos, extramuros de la ciudad de Santiago de Compostela", AIA, XX, t. 36, 1933, p. 414.

${ }^{33}$ Cfr. Fr. A. LÓPEZ, "Bibliografías de ilustres franciscanos gallegos", AIA, no 12, 1919, pp. 410411, 424-430, n²9 413-420; J. FILGUEIRA VALVERDE, "Cancioneiriño de Compostela", Nos, XIV, $\mathrm{n}^{\circ}$ 103, 25.VII.1932, pp. 122-123; A. COUCEIRO FREIJOMIL, Diccionario bio-bibliográfico de escritores, Bibliófilos Gallegos, Santiago de Compostela, 1952, II, pp. 165-166; Gran Enciclopedia Gallega, S. Cañada Ed., Santiago, 1974, 16, pp. 32-33; F. AGUILAR PIÑAL, Bibliografía de autores españoles del siglo XVIII, CSIC, Madrid, 1986, IV, p. 205, n. 1404.

${ }^{34}$ CNC, Francisco Antonio Martínez, Prot. 3578.

${ }^{35}$ Cfr. AHRG, Fuerzas eclesiásticas, leg. 27062-235: Fernández Noguerol aparece en 1689 como curador de las hijas menores que habían quedado de Jacobo Gil.

${ }^{36}$ AHRG, Fariña, leg. $14730 n^{\circ}$ 4: tanto la esposa como la hermana de ésta, Andressa, eran nietas de Juan do Souto y Theresa da Riva; padres éstos de Juan do Souto Pedrero, que había sido vecino de Carnoedo, casado con Catalina da Pedreyra. El Catastro de Ensenada registra como hijodalgo en San Julián de Mondego a Marcos de Bregondo, abastecedor de vino.
} 
2. Isabel María Gil da Pedreira Taboada, nacida en San Jorge de La Coruña el 9.VII.1679, casó con Pedro Álvarez Carballo, Alcayde de la Cárcel de La Coruña, probablemente en 1712 pues es de julio de ese año la escritura de dote firmada por el padre. Con autorización del mismo hizo un primer testamento el 25.V.1722 ante Pedro Pascual de Montenegro y otro, ya viuda, el 10.IV.1753. En esa fecha calculaba su edad en setenta y dos años, más o menos, y vivía en la calle de San Andrés, frente al Crucero de la Rua nueva. No sabía firmar. Sin sucesión, legó a las hijas del hermano mayor sus bienes, sustanciosa fortuna redondeada por su diligente marido con adquisiciones en ventas judiciales;

3. Juana Gil Taboada da Pedreira, casada en primeras nupcias con Gregorio López Labandeira, escribano de la Real Audiencia, y en segundas con José Varela Figueroa, receptor de la misma, cuyos descendientes volverán a enlazarse con la línea principal de la familia; y

D. José Antonio Gil Martínez Taboada da Pedreira. Nacido el 16.XII.1672 en San Jorge de La Coruña. Vivía indiferentemente en esta ciudad y en Mosteirón, donde radicaban sus vínculos y mayorazgo. En 1715 era Administrador de las Reales Rentas del Tabaco en La Coruña y su partido, más tarde Visitador General de las Reales Dehesas en el Reino de Galicia. Contrajo tres matrimonios, el primero con Juana Varela Pita da Veiga Reymondez de Figueroa ${ }^{37}$; el segundo con Teresa Brígida del Río Paz Cao y Cordido; del tercero con Ignacia Abellón no quedaron descendientes. Fueron hijos del primero:

1. Francisco Gil Taboada, muerto ya en 1772, que fue dueño y poseedor de la Casa principal de Mosteirón, tutor de sus hermanos durante la menor edad;

2. Nicolás Gil Taboada, "yncapacitado";

3. Ignacia Josefa Cayetana Gil Taboada Reymondez Figueroa, nacida y bautizada el 18.IX.1708 en San Jorge de La Coruña;

4. Juan Ignacio Joseph Gil Taboada Varela Figueroa, nacido en la parroquia de San Jorge de La Coruña el 29.I.1706. Su asendereada trayectoria - reflejada en una hoja de servicios repleta de comisiones entre lo militar, lo burocrático y lo organizativo $^{38}$ - lo llevó de Ceuta a la Habana, de Nápoles a Veracruz y al sitio de

37 El Catastro de Ensenada registra como hijodalgo en San Julian de Mondego a Joseph Varela Reymondez. Hay datos de varias operaciones de José Gil Taboada en AHRG, Gómez, leg. 18763-18: 1715, redención de un censo de su primera mujer; id. Gómez, leg. 18641-36: 1719, sobre pagos; id. Figueroa, leg. 9019-4: 1720, sobre la casa y granja de Mosteirón que poseían los padres de su primera mujer; id. Figueroa, leg. 17083-65: 1722, contra el cura de Mosteirón que perturbaba la posesión de una tarima en la iglesia.

38 Apéndice $n^{\circ} 2$. 
Gibraltar para recalar al fin como dirigente de la Real Fábrica de jarcia, lonas y lanillas de Sada, dependencia importante para el servicio del Arsenal ferrolano. Casó con María de la Torre y León, de familia de hijosdalgo notorios de Vélez y Loja en el Reino de Granada, cuyos padres fueron Francisco de la Torre y Laura Teresa de León Rodríguez. El Catastro de Ensenada lo describe así el 5.XII.1752: "D. Juan Gil Taboada, Ministro de la mencionada Real fábrica, casado; su hedad 42 años. Tiene dos hijos menores en su compañía a la suegra una criada y de sueldo al año quatrocientos y ochenta escudos, que suman reales quatro mill i ocho cientos"39. Que su ingenio y capacidades no se limitaban a lo técnico de su profesión queda atestiguado en los festejos por él organizados en Sada en honor de Carlos III siguiendo la arraigada costumbre académica de conmemorar los fastos de la monarquía. Dejó constancia de ellos su amigo y vecino en Mondego José Cornide ${ }^{40}$. El 22.IV.1774 hacía testamento disponiendo ser enterrado en la capilla de San Andrés del Arsenal de la Graña, de donde era vecino.

Hijos de este matrimonio fueron:

- Carlos, casado con Juana Franco, vivía en 1774 con su padre, igual que los demás hermanos solteros. En 1780 era oficial supernumerario del Ministerio de Marina. Fue el último poseedor de la casa de Mosteirón. Siguiendo la costumbre de resaltar los méritos de otros miembros del propio clan, aducía en su propia hoja de servicios los méritos del padre con detalles que éste había se dejado en el tintero ${ }^{41}$;

- Manuela, casada con Baltasar Castañeda, primer oficial de la Contaduría de Marina de Ferrol; en 1786 era Comisario de provincia de la Marina y residía en Cartagena de Levante;

- Juana Beatriz Marta Francisca Victoria, bautizada en Santa María de Sada el 29.VII.1756, que casaría con su tío Andrés Gil Taboada el 9.V.1781. Murió en Soñeiro el 8.VII.1830 habiendo hecho testamento. Sabía firmar;

\footnotetext{
${ }^{39}$ Comparecía también como propietario en San Julián de Mondego: "Don Juan Gil Taboada, v ${ }^{\circ}$ de Sada, tiene una casa terrena, alquiler 12 rs. al año; monte bajo 14 ferrados; 4 ferrados de monte; 16 ferrados de tierra sembradura, un ferrado idem, 7 ferrados idem; 2 jornales de viña, id. 12 jornales; 4 ferrados de monte bajo; 3 ferrados de tierra sembradura; 10 jornales de viña ..."; en San Julian de Osedo poseía 7 ferrados de sembradura de segunda calidad.

${ }^{40}$ Apéndice $n^{\circ} 3$.

${ }^{41}$ Apéndice no ${ }^{\circ}$. Más datos en CNC, Nicolás Antonio Barral Prot. 5197-5206, f. 128: 16.X.1780 arrienda una casa en la Pescadería de La Coruña; AHRG, Prot., leg. 1552, f. 119: escritura de fianza del mismo en 1792; AHRG, Prot. leg. 1554: junto con su madre, que firma con buena letra aunque trémula, da un foro el 15.IV.1792; CNC, Roque de Noya Prot. 5465, 20.VI.1792: venta a Gerónimo Hijosa como apoderado de su madre.
} 
- Francisco María, bautizado en Sada el 17.XI.1757; en 1787 vecino de Ferrol y oficial de la Contaduría de Marina; casado con Manuela de Prado Ribadulla; y

- Andrés, quien recibió cuatro mil reales de su tío Andrés "para equiparse y embarcar para los reinos de Nueva España" a donde iba con el Alcalde electo de Tensidan y Atempa D. Manuel Martínez Elguero "por su escribiente" 42 . De su prematura muerte cuando era gobernador del castillo del golfo de Honduras nos informa la carta de su esposa Rosalía Figueroa y Taboada desde Guatemala en 3.XII.180743.

La segunda esposa de José Gil Taboada da Pedreira fue Teresa Brígida del Río Paz Cao y Cordido, hija de Rafael Antonio Paz y Cordido y Teresa del Río. Teresa murió sin testar en la parroquia de San Jorge de La Coruña el 5.VIII.1731, donde se bautizaron sus hijos. A su entierro asistió la Cofradía de Todos los Santos y la Comunidad de San Francisco. De este matrimonio nacieron:

5. Joseph Manuel Ramón Antonio, el 1.IX.1721. Era Capitán de caballería ligera en el Regimiento de San Salvador, provincia de Guatemala; murió soltero en Madrid el 13.IV.1777.

6. Joseph Liborio Antonio, Alcalde mayor de la provincia de Tlamanalco, Alcalde mayor interino de Santa María de Jonatla y Tetela, Subdelegado de ventas y composiciones de tierras de la misma Jurisdicción durante tres años; el 14.II.1775 era Teniente de Capitán general de la Provincia de Chalco y Administrador de la Renta del Tabaco en el partido de San Juan Teotihuacán y su Alcalde mayor. Casado con Juana Francisca de la Serna, al morir el 30.VIII.1778 dejaba varios hijos menores. Fue enterrado en la capilla el Sagrario de la catedral de la misma ciudad;

7. Antonio Ventura Ignacio, nacido el 15.VII.1722, era en 1770 Teniente del Real de Minas del Doctor en Cadereyta; en 1771 Alcalde mayor de San Juan Teotihuacán. Casó en Méjico con Bárbara del Real, de quien vivía separado desde 1756. El 7.XI.1772 hizo testamento en la misma ciudad, donde murió el 13.IV.1777;

8. Manuel José Antonio Andrés, nacido el 24.XII.1723;

7. Josefa, soltera en 1763 y a punto de entrar como "monja seglar en el convento de Santa Bárbara de La Coruña". El 13.XI.1773 da un poder junto con su hermano Andrés ${ }^{44}$. Murió en 12.XII.1788 habiendo hecho testamento ${ }^{45}$;

\footnotetext{
42 AHRG, Prot., leg 1652, 12.XII.1788: satisfacción de esa deuda por la madre en bienes raíces.

${ }^{43}$ Apéndice $n^{\circ} 8$.

${ }^{44}$ CNC, Prot. Juan Andrés del Busto, 4995.

45 AHRG, Prot. 157, f. 237.
} 


\section{Manuela; y}

9. Andrés Juan José, que sigue.

E. Andrés Juan José Gil Taboada del Río Paz y Cordido, bautizado en San Jorge de La Coruña el 27.II.1725. Como sus hermanos, pasó a Méjico alrededor de 1742, iniciando allí una carrera que concluiría en España. En su hoja de servicios, igual que en la de su hermanastro Juan, la indicación del parentesco con ilustres miembros de la familia como Don Felipe y Don Cayetano Gil Taboada, arzobispos respectivamente de Sevilla y de Santiago, contribuía a corroborar las dotes personales. En 1762 presentaba información de nobleza por sí y por sus hermanos mientras se hallaba en la corte de Madrid, "adonde ha venido a sus pretensiones honoríficas". Al año siguiente firmaba una escritura de obligación al embarcarse en Cádiz para servir como Alcalde mayor de la Villa de Cadereyta, en Méjico. Desempeñó varios empleos en la Nueva España fundando pueblos de indios, recaudando el quinto de la plata y superando con honor el juicio de residencia al terminar su misión en aquel país ${ }^{46}$. Al regresar a Galicia fue Juez Real de la Jurisdicción de Miraflores. Queda alguna prueba de su actuación como primera autoridad en este territorio - algo más extenso que el del actual ayuntamiento de Oleiros ya que incluía también Sada -, donde ciertos dimes y diretes a que se vio abocado inter pares, o sea, con algún arriscado hidalgo de la zona, debieron hacerle añorar el gobierno in partibus barbarorum ${ }^{47}$. En 1779 pagaba ornatos y servidumbre de la

${ }^{46}$ Cfr. Apéndice $n^{\circ} 4$.

${ }^{47}$ Cfr. AHRG, Protocolos, leg. 1649, f. 32: Cárcel de La Coruña, 19.XII.1785. "D. Andrés Gil Taboada $\mathrm{v}^{\mathbf{o}}$ de San Nicolás de Mosteirón y Antonio de Leis y Parga esn ${ }^{\circ}$ de S. M. y de numero de Santa María de Sada, fueron presos el 6.X.1785 sin saber por qué se los arrestaba hasta que pasados algunos días llegaron a saber había sido en virtud de representación echa por D. Pedro Bazán, suponiendo delitos que no han cometido, antes bien, procedido con todo arreglo en el asunto que suscitaba D. Pedro Bazán ...". Pide libertad bajo caución pero el 20.I.1786, y estando en la cárcel, da poder para que le defiendan en el pleito "con varios que han tenido el arrojo y atrevimiento de propasarse al lugar de Vilar, $\mathrm{f}^{\mathrm{a}}$ de S. Martin de Meirás [...] a cortarle de noche porción de árboles frutales de mucha estimación, entre ellos un castaño, pretendiendo destituirlo de su propiedad, que ha heredado". Cfr. C. MARTÍNEZ BARBEITO, "Impresos gallegos de los siglos XVI, XVII y XVIII", CEG, Anejo XVII, 1960, pp. 82-83: "Real Auto de S. E. los Señores de la Real Audiencia de Galicia Por el que se declara por ilustre, noble y distinguida la Familia de Don Pedro Bazán y Mendoza: Se da por nulo, y atentado todo lo obrado a pedimento de D. Pedro Pardo Montejano; Y por irracional el disenso de este para contraer Matrimonio su Hijo D. Juan con Doña Luisa Bazán: Con las Multas, Apercivimientos, y mas que sobre el particular contiene. Confirmado, agravado y ejecutoriado por Real Orden de 19 de Septiembre de 1787. Mandado imprimir a costa del D. Pedro Pardo, y circular por todas las ciudades de Voto en Cortes; y mas partes a donde el D. Pedro Bazán de Mendoza lo solicite [... La página 3 es una portadilla que reza:] Real Auto de S. E. los Señores de la Real Audiencia de este Reino, pronunciado en Sala segunda de Justicia en cinco de Febrero de mil setecientos 
iglesia de San Nicolás de La Coruña. Casó el 9.V.1781 en San Nicolás de Mosteirón con su sobrina - hija del medio hermano Juan Gil Taboada Varela - Juana Beatriz Marta Francisca Victoria Gil Taboada de la Torre y León.

Constan las fechas de nacimiento de los hijos (bautizados todos en la parroquia de Mosteirón menos la última, que lo fue en San Julian de Mondego) de puño y letra del padre en un cuadernillo de confección casera titulado Quaderno util para saber el Año Dia y ora en que han nacido los Hijos que Dios Nro. Sr. Fue servido darnos a mi Dn. Andrés Gil Taboada y a mi esposa $D^{a}$ Juana Gil de la Torre desde el año de 1781 en que contragimos Matrimonio. A cada uno se repite la anotación "fue Dios servido sacar a luz un niño [...] por todo damos gracias al Todopoderoso ", "doy a la Divina Providencia gracias por tantos veneficios y lo firmo". Fueron estos hijos:

1. José Juan María de los Dolores Cesáreo, bautizado el 25.II.1782. Siguió la carrera militar y en 1802 se hallaba en Montevideo, "en la frontera de los portugueses", como soldado distinguido del Regimiento de Dragones de la Capital de Buenos Aires. Casó en esta ciudad con Victoria Pestaña el 22.X.1806. El 23.VI.1802 dio poder a su madre ante el escribano público de Montevideo Juan Antonio Magariños para tomar posesión judicial del mayorazgo y bienes que le correspondían por muerte su padre. Moriría en 1807 en el ataque inglés a Montevideo ${ }^{48}$;

ochenta y siete, por el que se declara por nulo, injusto, y atentado todo lo echo, y obrado por el Juez Real de la Jurisdicion de Miraflores, D. Andrés Gil Toboada [sic], y el Escrivano de Numero Antonio de Leis y Parga, y el Lic. D. Josef Martinez, Asesor con quien se acompañó para la determinacion de los Autos. Sobre el consentimiento que D. Juan Pardo Capitan del Real Cuerpo de Artilleria pidio a su Padre D. Pedro Pardo Montejano, para contraher Matrimonio con Daña [sic] Luisa Bazan, Hija de D. Pedro Bazan y Mendoza, la que se reboca, y a este se le declara y su Familia, por distinguida, ilustre, y honrada, sin nota alguna que le pueda causar perjuicio a el, ni sus descendientes; y por irracional el disenso de dicho D. Pedro Pardo; y concede licencia al D. Juan Pardo para contraher Matrimonio con Doña Luisa Bazan, en canformidad [sic] de la Real Pragmatica de 23 de Marzo de 1776, con los apercibimientos, multas, y prevenciones que contiene. Mandado consultar a S. M., imprimir, y circular a costa de D. Pedro Pardo por todas las Ciudades del Reino de voto en Cortes, y otras cualesquiera partes a donde lo solicite D. Pedro Bazan en virtud de expresa Real Orden de S. M. comunicada a la Real Audiencia en 28 de Septiembre de 1785. Confirmado, agrabado, y executoriado en todas sus partes en virtud de otra Real Orden de 19 de Septiembre de 1787. En Santiago por D. Ignacio Aguayo y Aldemunde Impresor del Real Acuerdo, Intendencia y Reales Rentas". Se dan a conocer las sanciones en que han incurrido no solo D. Pedro Pardo sino todas las personas con autoridad y sin ella que le ayudaron contra D. Pedro Bazan. Otros actos en que intervino Andrés Gil Taboada: CNC, Prot. 5197-5206, Nicolás Antonio Barral, f. 81 y f. 131; AHRG, Protocolos, leg. 1553: 3.VII.1791 vende un monte en Meirás.

${ }^{48}$ Apéndices $n^{\circ} 6$ y 7. 
2. Juan Dionisio, nacido el 8.IV.1783;

3. María Ana Josefa Micaela, el 8.V.1785;

4. Ana Josefa Ubalda, el 16.V.1786. Casó el 26.II.1827 con Andrés García, hijo éste de Gervasio García y Francisca Yáñez, vecinos de San Jorge de Iñás. Al morir sin sucesión testó a favor de sus sobrinas;

5. Francisca de Paula Josefa, el 2.IV.1788; casada con Gaspar María Maldonado Pita da Veiga, de Puentedeume ${ }^{49}$. En 1827, ya viuda, litiga sobre posesión de bienes vinculares y su hermano Gonzalo aparece como curador ad litem de sus hijos menores Joaquín, Josefa y Carmen Maldonado. En 1839 nombra maestro en San Jorge de Lorenzana, patronato de su marido, como apoderada suya;

6. Carlos María, el 27.I.1790. Igual que su hermano menor Gonzalo aparece incluido en una relación de "mozos de la parroquia de Soñeiro que desde 1808 fueron para el ejército" 50 ;

7. Gonzalo Francisco Antonio, el 26.X.1791, que sigue;

8. Ramona Josefa María, el 31.VIII.1796, bautizada en San Julián de Mondego. Casó con Manuel María de Leis Miranda ${ }^{51}$, quien el 5.VI.1834 admitía ante notario haber sido "arrastrado de la fragilidad humana, faltando a los deberes matrimoniales y dando margen a diferentes pendencias con su ignocente mujer que redundan en perjuicio de ella y sus tiernos hijos"; "arrepentido de sus desbaríos" entrega su fortuna a la esposa, quien nombra administrador a su hermano Gonzalo. En 1836 y como apoderada de su marido nombra maestro en la escuela de San Jorge de Lorenzana, cuyo patronato ejercía.

F. Gonzalo Francisco Antonio Gil Taboada y Gil Taboada (26.X.179119.XII.1854). Casó el 30.IV.1812 en la parroquia de San Nicolás de La Coruña con Andrea Conchado y Pardo (1792, S. Julian de Soñeiro - 14.V.1874). Era hija ésta de Mauro Conchado, nacido y bautizado en Santa María de Cambre en 1764, y de María Juana Pardo da Rigueira, nacida en Soñeiro en 1770, que contrajeron matrimonio en Soñeiro el 16.I.1790. Gonzalo participó en la Guerra de la Independencia como Capitán, constando que "es un joven de buena conducta y procedimientos, y que no sólo tiene la acetación de los indibiduos de la Compañía de su mando

\footnotetext{
${ }^{49}$ Cfr. MARTÍNEZ BARBEITO, Torres, ..., cit., p. 288.

${ }^{50}$ AMC, Guerra Independencia. Alistamiento III.

${ }^{51}$ Cfr. MARTÍNEZ BARBEITO, Torres, ..., cit., p. 410: la esposa, Ramona, no fue hija de dos primos, como se afirma ahí, sino de tío y sobrina.
} 
sino la general del País"52. En 1820 fue nombrado elector de parroquia ${ }^{53}$. Como Alcalde primero constitucional de Sada en 1839 se enfrentó con la Junta Diocesana de Santiago que entendía en la exacción de diezmos. En 1844 hizo reconstruir la iglesia parroquial de Soñeiro, donde no se permitía decir misa por amenazar ruina. De este matrimonio nacieron:

1. Ana María Manuela, el 25.I.1813, en Santa María de Oleiros. Casada el 21.VI.1847 con Antonio Pardo Suárez, falleció el 7.VII.1851;

2. Manuel, el 3.III.1814, en Soñeiro. El 21.III.1832 su padre exhibía información de nobleza y limpieza de sangre para que este hijo primogénito y el siguiente, Juan José, se colocasen en el servicio de S. M. en la clase de oficiales de Milicias en el Regimiento Provincial de Betanzos. Siendo Teniente moriría el 13.VI.1837 en acción de guerra en el Valle de Mena (Burgos);

3. Juan José, el 27.V.1815. Teniente en la tercera Compañía de Cazadores del Regimiento Provincial de Betanzos, fue hecho prisionero en la acción del Campo de la Cruz, jurisdicción de Solórzano (Santander) y, "sin herida alguna", fusilado por los carlistas el 3.V.1838;

4. Francisca Antonia, el 12.VI.1817;

5. Antonio, el 6.V.1819. Como sus hermanos mayores, pero con mayor fortuna, siguió la carrera militar: el 9.XII.1837 era Subteniente de Bandera del Regimiento de Milicias provinciales de Betanzos; el 22.IX.1839 subteniente de la Compañía de Granaderos del mismo Regimiento; el 3.VIII.1841 tenía igual cargo en Infantería; el 27.III.1843 Teniente del Batallón provincial de Orense; el 12.IX.1852 Capitán graduado de Infantería; el 12.VII.1860, atendiendo en particular a los servicios prestados en el alzamiento de 29.IX.1854, se le nombra Capitán efectivo de la misma arma: carrera truncada al tener que hacerse cargo de la tutoría de nueve sobrinos menores, hijos de su hermana Juana Gil Taboada y Antonio Pardo Suárez. Murió en Soñeiro el 21.VII.1896 y otorgó testamento el 19.VII.1896 ante el notario de Betanzos Pérez Alonso;

6. Gonzalo Juan José, el 6.III.1821; en 1864 era vecino de La Habana, y allí seguía teniendo negocios en 1881. En 1886 dio poder a Francisco María de la Iglesia González para reclamar ciertas deudas en nombre de sus sobrinos al morir la madre de éstos. Falleció en Soñeiro el 26.VI.1901 e hizo testamento el 11 de mayo del mismo año ante el notario de Betanzos Pérez Alonso;

${ }^{52}$ AMC, Guerra Independencia XI, 14.X.1811. AMC, Guerra Independencia XI, 14.X.1811 AMC, Guerra Independencia XI, 14.X.1811.

${ }^{53}$ Cfr. Diario Patriótico Constitucional de La Coruña, no 74, 12.V.1820. 
7. Ramón María, el 24.II.1823 y murió el 24.VIII.1824;

8. María Josefa, el 31.VII.1824;

9. Joaquina Gaspara Francisca, gemela de un niño que murió al nacer el 5.XII.1826;

10. Nicolás María del Carmen, el 15.VII.1829; murió a los pocos días;

11. Juana María Teresa, el 24.X.1830. Casó con Antonio Pardo Suárez el 11.III.1855, con quien tuvo los hijos que quedan ya reseñados al describir la familia Pardo. Falleció el 7.XI.1885 e hizo testamento el 20.X.1885 ante el notario Francisco Ramos y Vázquez;

12. Ramón Andrés, el 6.IV.1836. En julio de 1853 iba a embarcarse para la Habana pero tuvo que aplazarlo porque "el buque es bueno para carga mas no para pasajeros: solo tiene cuatro dormitorios en una camara muy pequeña que deben ocupar los oficiales. Lleva gente de Santa Marta en un sollado que están haciendo en la bodega". Establecido en La Habana a partir de 1855 , en 1891 estaba viudo y en ignorado paradero.

Estos datos sobre nacimientos y bautizos están registradosdadoen sendos cuadernillos formado con medios pliegos cosidos con cordel, de puño y letra del padre de los recién nacidos, el primero titulado Quaderno util $p^{a}$ saber el año, día y ora, en que an nazido los hijos que Dios Ntro. Sr. fue servido darnos a mi, Dn. Gonzalo Gil Taboada y a mi esposa $D^{a}$ Andrea Conchado y Pardo, desde el año de 1812, en el que contrajimos Matrimonio a 28 del mes de Abril de dicho año, en la ciudad de La Coruña, parroquia de San Nicolás en donde tambien fuimos velados.atos sobr generación constan de puño y letra de Antonio Pardo, Tampoco se olvidan aquí las "gracias a Dios por todo", repetidas a cada nacimiento. Los de la última, en una libretita en octavo donde los sucesores fueron anotando otras fechas de interés familiar.

\section{APÉNDICE}

1. Reyes de armas de Su Majestad Católica el Sr. D. Carlos III, Rey de España, de las Indias orientales y occidentales, Islas y Tierra Firme del mar Océano, de los que asisten cerca de su Real Persona.

Certificamos, en virtud de la Real facultad con que nos hallamos, aprobada y ratificada por resolución de Su Majestad de 17 de Noviembre de 1753, en que se mandó que ninguna otra persona que los Reyes de Armas se entrometieran a hacer los entronques, genealogías y demás instrumentos privativos de estos empleos, que 
por los registros, papeles originales y Libros de Armería que se hallen en nuestro poder, que tratan de las ilustres casas y solares de Hijos Dalgo de estos Reinos: consta que la nobleza de la sangre adquirida a repetidos esfuerzos de la virtud es la única distinción que tienen entre si los hombres. De ella nace que conociendo todos un mismo origen y principio, adquieren unos más estimación que los otros. Esta separación es y ha sido en todas edades y naciones tan bien recibida que por ella sufrieron los generosos espíritus los mayores peligros por alcanzar lugar más preeminente entre los demás hombres. Por esta razón los Hebreos y Romanos traían en sus sandalias aquellos cruzantes de hechuras de medias lunas por jeroglífico de ser la nobleza semejante a la luna que en su principio es obscura, en su aumento clara, en su mayor auge resplandeciente y en su declinación hace retroceso a las primeras tinieblas de su origen. Cuya doctrina los estimulaba a su debida conservación para no incurrir en la amenaza que hizo Dios a los Hebreos por Esaías, diciéndoles que había de empezar su castigo quitándoles las lunas de su calzado, que era lo mismo que degradarlos de la misma nobleza que contrajeron sus descendientes; y por no incurrir en esta justa sentencia la tuvieron siempre presente las familias de que trataremos, con la de Casiodoro cuando dijo:

Rustica progenies ne fuit haverse modu sed vexa nobilitas ne fuit carere modo [sic]

Y siendo entre todas las políticas naciones celebrados con específico aprecio los linages que provienen de progenitores heroicos, goza de tan justa debida prerrogativa la casa de Gil pues como asegura Juan Francisco de Hita en sus originales, trae su origen de la Casa Real de León, porque el Rey D. Alonso, que en Doña Teresa Gil tuvo por hijo a Martín Alonso Gil, que se halla sepultado en el Monasterio de Santi Spiritus de Salamanca; y del matrimonio que había contraído con Doña María González Girón hubo por hijos a Don Gil Alonso y a Fernando Gil, progenitores de Martín Gil, Adelantado mayor por el Rey Don Pedro del Reyno de Murcia, a quien hizo matar este príncipe en las alteraciones que tuvo con su hermano Don Enrique. Don Gonzalo y Don Manrique Gil, Adelantados mayores que asimismo fueron del Reino de León y Asturias el año 1260; y Don Martín Blasco Manrique Don Juan Gil, que hicieron maravillosas acciones en la conquista de Sevilla.

De esta misma casa, como refiere el citado Juan Francisco de Hita descendió la que se rreconoce en el Reino de Galicia, cuyos poseedores han servido en las conquistas y batallas contra los moros en beneficio de sus monarcas, la religión y la patria ostentando siempre lo heroico de su principio y la justa veneración que se debe a sus progenitores, lo que continuaron sus ascendientes señaladamente Don Jacobo Gil Taboada, vecino de la feligresía de Mosteirón agregada a la de San Julián de Osedo, Provincia de Betanzos, Arzobispado de Santiago de dicho Reyno 
de Galicia, cuya Casa fue fundada despues de su conquista por entre las ciudades de Lugo y Orense en la era que hoy llamamos de Taboada por un valeroso Capitán cuyo nombre tomó de su fundador contraiendo sus descendientes ilustres alianzas con las Casas de los Condes de Mazeda y Taboada, Grandes de España, y ostentando por armas escudo azul con dos mesas de plata y orla de oro con ocho calderas negras que unieron a las de los Giles, que son: de plata con dos leones pardos y orla azul con ocho crecientes de plata como se iluminará en el escudo que va al principio de esta certificación y se estampan en el siguiente

Caso dho. Don Jacobo Gil Taboada con Da María Pedreira, cuya Casa compite con la más decorosa emulación, lustre continuado y venerable antigüedad asegurando D. Juan Francisco de Hita y Diego Barreiro que un caballero Fernán se halló el año de setecientos dieciocho en Covadonga a la elección de el Rey Don Pelayo y que su hijo llamado Suero le sirvió en la conquista de Oviedo, León y otras el que tuvo por hijo a Don Monino que casó con Doña Juana Bermúdez, de quien fue Froila que cercó a Oviedo en cuyo sitio murió y es el progenitor de los de Pedreira cuya ccasa husa por armas escudo de oro con un castillo ahumado situado sobre unas peñas como se iluminará en el cuarto cuartel del referido escudo general y se manifiesta en el siguiente

Del matrimonio que contrajeron los expresados Don Jacobo Gil Taboadsa y Doña María Pedreira fue hijo Don José Gil Taboada, vecino de la referida parroquia de San Nicolás de Mosteirón, que sirvió a S. M. de Administrador de las reales rentas de Tabaco de La Coruña y su provincia y Visitador general de las Reales Dehesas de dicho Reyno de Galicia; el casó primero con Doña Juana Varela Reymondez de quien tiene por hijos a Don Francisco Gil Taboada, poseedor de la Casa principal y mayorazgos de Mosteiron, Don Nicolás y Don Juan Gil Taboada, Gobernador de la nueva ciudad de Esteiro y Ministro de las Reales fábricas de jarcias y lonas de la Villa y puerto de Sada. Y de segundas nupcias casó con Doña Teresa del Río, hija de Don Rafael Paz y Cordido y Doña Ana del Río, cuyas casas son de tan elevado principio que, como aseguran los referidos autores, tiene la del Río su solar en dicho Reino de Galicia en la Jurisdicción de Suevos, de donde son señores y descienden del Príncipe Perseo que vino el año de 1186 huyendo e hizo su asiento en tierra de Foz, en el mismo reino, la cual pobló y viniendo posteriormente Leonisa, hija del Rey Carlos de Francia, fue aposentada en casa de un caballero de la familia del Río donde dio a luz la infanta Doña Berenguela, que casó con él en cuya memoria trae esta Casa escudo de plata con tres lises azules, y en la base ondas de agua, como se iluminará en el primer cuartel de dicho escudo y en el siguiente

La casa de Paz trae su origen y principio de el Conde Don Tello, hermano de los Reyes Don Pedro y Don Enrique segundo por cuyas reales alianzas pertenecen 
a la Casa del Río cuatro líneas reales como va propuesto siendo dignos de los mejores elogios Don Carlos y Don Pedro Paz, excelentísimos capitanes en Italia con el Gran Capitán y Don Lope Paz Bailío Nigropontico y embajador en Malta del Gran Turco. Esta casa lleva por armas escudo azul con diez roeles de oro como se iluminará en el segundo cuartel de dicho escudo que principió este despacho y en el siguiente

No goza de menores prerrogativas la referida Casa de Cordido situada en dicho reino de Galicia por derivar de los antiguos godos y el primero de quien se halla memoria es de Don Munino que floreció el año de 816 reinando Don Alfonso el Casto y era deudo y amigo de Bernardo del Carpio y de su muger Don Bermudez tuvo a Froila que cercó a Oviedo en suyo sitio murió dejando por sucesor a Melendo de quien procede esta Casa. Por armas campo verde con dos corderos blancos como se estampará en el tercer cuartel de dicho escudo y se iluminará en el siguiente

Del primer matrimonio que contrajo el expresado Don José Gil Taboada con $\mathrm{D}^{\mathrm{a}}$ Juana Varela Reymondez son hijos Don Francisco, poseedor de la casa principal y mayorazgos de Mosteirón, Don Nicolas y Don Juan, Gobernador de la ciudad de Esteiro y Ministro principal de las Reales fábricas de jarcias y lonas de la Villa y puerto de Sada, y del segundo con $\mathrm{D}^{\mathrm{a}}$ Teresa del Río lo son Don Manuel, Don Andres, Don José, Don Bentura y Doña Josefa, como todo se justifica de una probanza rendida a pedimento de dho. Don Andrés ante la Justicia ordinaria de la Jurisdicción de Miraflores con citación de su Procurador síndico general en 15 de marzo de este año de la fecha ante Francisco Javier Vaamonde escribano de su número en la que tambien consta que los Ilustrísimos Don Felipe Gil Taboada Presidente de Castilla y Arzobispo de Sevilla y Don Cayetano Gil Taboada que lo fue de Santiago eran sus parientes inmediatos, todos caballeros hijosdalgo notorios de sangre y sirviendo los escudos de armas de luceros y permanentes astros en el firmamento de la Historia, para hacer más venerables y respetuosas las familias distinguiéndolas según los grados de las dignidades perpetuas o temporales y haber tomado su origen de aquellos primeros duelos que la envidia, furor y ambición de los hombres introdugeron en los más antiguos siglos para hacerse más formidables y espantosas a la vista de sus enemigos. Daremos puntual razón de su significación manifestando el oro de las virtudes Justicia y de las calidades mundanas Nobleza, amor al Príncipe y constancia en las empresas con obligación de defenderle y hacer bien a los pobres. La plata significa de las virtudes Humildad, y de las calidades mundanas Limpieza de la sangre con obligación de defender las doncellas y amparar los huérfanos. El color azul significa de las virtudes Justicia y de las calidades mundanas Nobleza y Lealtad al Soberano y obligación de socorrer a 
los que no tienen [aquí esta roto el original y falta una palabra, se cree es 'reservado'] sus servicios. El verde significa de las virtudes Esperanza y de las calidades mundanas, onestidad, obediencia, constancia y secreto con obligación de socorrer a las viudas. Los crecientes son unas lunetas en figura de lunas y se traen por presagio de Grandeza. Las calderas representan ricahombría. Los leones los valerosos y esforzados guerreros. Los castillos asilo y salvaguardia. Las lises por participación con los Reyes de Francia. Los roeles caballeros escogidos. Las ondas se traen en honor y memoria de haber venido a Galicia en una nave el Príncipe Perseo. Las mesas haber mantenido a su costa hombres de guerra. La zelada representa los generosos pensamientos y expediciones secretas que proyecta la cabeza y ejecutan las manos, y los plumajes y penachos son insignias y trofeos bélicos permitidos a los valerosos guerreros. De cuyas armas usarán los expresados Don Manuel, Don Andrés y Don José Gil Taboada en sus portadas, sellos y sepulcros y demás partes acostumbradas, con un morrión de acero bruñido, enteramente de lado, la bisera abierta, con tres regillas clavadas de oro, como la bordura, y forrada de rojo. De cuyo pedimento damos la presente, firmada de nuestra mano y nombre y sellada con el sello de nuestras armas, dejando tomada la razón en los libros de nuestro cargo.

Madrid a 29 de Agosto de 1762.

[Está rubricado] Manuel Antonio Brochero - Julián José Brochero.

[En la última plana dice así:]

\author{
Blasón de las Armas \\ Y Genealogía de las \\ Ilustres Casas de Gil \\ Taboada Río Paz y Cor- \\ Dido \\ Los Giles y los Taboadas tienen por \\ Armas Blasón ser parientes \\ muy cercanos de los Reyes de \\ León
}

2. Relación de los servicios de Don Juan Gil Taboada, oficial de la Clase de segundos de la Contaduría Principal de Marina del Departamento de Cadiz, y Ministro Director de la Real Fabrica de Jarcia, Lona, y Lanillas del Puerto de Sada.

Consta, que es hijo legítimo, y de legítimo matrimonio de Don Joseph Gil Taboada, y de Doña Juana Barela Reymondes de Figueroa, naturales de la 
Feligresia de San Nicolás de Monteiron [sic] en el Reyno de Galicia; quienes igualmente que sus ascendientes han sido, y son Christianos viejos, Hijos dalgo, y de conocida Nobleza, y como tal el nominado su padre obtuvo los empleos de Administrador de las Rentas del Tabaco de la Ciudad de la Coruña, y su jurisdiccion, y de Visitador general con las facultades correspondientes de las Reales Dehesas de S. M. en el mismo Reyno, cuya familia se halla emparentada con el Señor Don Phelipe Gil Taboada, Governador que fue del Real, y Supremo Consejo de Castilla, y Arzobispo de Sevilla, y con el Señor Don Cayetano Gil Taboada, Arzobispo que tambien fue de Santiago en el expresado Reyno.

Que el nominado Don Juan sirvió de Cadete en el Regimiento de Infantería de Granada desde once de Marzo del año de mil, setecientos, y veinte, y dos, hasta el mes de Julio de el de mil, setecientos, y treinta, en cuyo tiempo lo continuó en las Plazas de la Coruña, San Sebastian, y Santander, y se halló en el sitio de Gibraltar el de mil, setecientos, y veinte, y siete hasta su fenecimiento, y posteriormente de Guarnicion en Zeuta mas de dos años sin intermision.

Que el año de mil, setecientos, y treinta, y siete, se hallava de Maestre de Jarcia de la Real Armada del Navio del Rey nombrado San Geronymo (Alias) el Retiro, en el qual conduxo desde el Puerto de Cadiz, al de la Habada [sic] diferentes pertrechos de Guerra, y otros efectos, los que entregó a los Oficiales de la Real Hacienda de aquellas Caxas, desde cuyo Puerto, pasó al de la Vera Cruz, en el que igualmente entregó a los Oficiales Reales de el todos los pliegos, Caxones de ellos, y Cartas de S. M. y del Real Servicio, que se pusieron a su cuidado, y en su virtud le se dio la Certificacion de Finiquito correspondeinte [sic] de la solvencia de todo quanto fue a su cargo desde veinte, y dos de Septiembre del citado año de mil, setecientos, y treinta, y siete, hasta quince de Julio de mil setecientos, y treinta, y ocho.

Que el de mil, setecientos, y treinta, y nueve se le nombró por Escribano de la Real Armada con destino a servir desde luego en el Pingüe San Nicolás, del qual se le trasladó a exercer su empleo en la Fragata del Rey nombrada San Juan.

Que hallandose de Contador de Navio de la Real Armada, y conviniendo que todos los empleados en ella tuviesen nombramientos formales por donde constase el empleo que cada uno obtenia, le despachó el Señor Marqués de la Ensenada por ausencia del Serenisimo Señor Infante Don Phelipe, Almirante General, y como Lugar Teniente General de S. A. el correspondiente al mismo empleo de Contador en quince de Febrero de mil, setecientos, y quarenta, y seis.

Que sucesivamente se le nombró para que pasase al Puerto de Sada a asistir, e intervenir como Ministro en las Obras y Reparos, que de Orden de S. M. y de 
cuenta de su Real Hacienda se debían hacer baxo la direccion, y disposicion del Señor Don Cosme Albarez, Gefe de Esquadra de la Real Armada, y Comandante General del Departamento de Marina del Ferrol en la Casa de la Fabrica de Jarcia, Lonas, y Lanillas establecida en el [sic] aquel Puerto, y aviendo pasado a su destino dio las providencias correspondientes a su actividad, y zelo, y sirvió el empleo de Depositario de los Caudales destinados para la mencionada Fabrica, y Edificios, que para ella se construyeron, desde veinte, y tres de Noviembre de mil, setecientos, y quarenta, y nueve, hasta primero de Junio de mil, setecientos, y cinquenta, y quatro, despues de lo qual se liquidó la cuenta del importe de tres millones, ciento, y ochenta y un mil, setenta reales, y veinte maravedis de vellon, que para la satisfaccion de los gastos causados en lo referido, le fueron entregados de caudal de la Real Hacienda, y resultó aver distribuido, y satisfecho en el citado tiempo, y los mismos gastos, la propia cantidad, en cuya virtud se le dio tambien la Certificacion correspondiente de Finiquito, y se le restaron los cargos que le estaban formados.

Que por Real Cedula de siete de Julio de mil, setecientos, y cinquenta, y siete, se sirvió S. M. en atencion a sus meritos, y servicios, de promoverle del enunciado empleo de Contador de Navio, al de Oficial de la Clase de segundos de la Contaduría principal de Marina del Departamento de Cadiz, que obtiene igualmente, que el de Ministro Director de la enunciada Real Fabrica de Jarcia, Lonas, y Lanillas del Puerto de Sada, el qual se halla exerciendo a satisfaccion del señor Don Antonio de Perea, Intendente general del enunciado Departamento del Ferrol.

Y ultimamente, que sus dos hermanos Don Joseph, y Don Andrés Gil Taboada, el primero sirvió interinamente tres años la Alcaldía Mayor de Santa Maria de Jonatla, y Tetela en las Provincias de la Nueva España, y de Juez Subdelegado de Ventas, y Composiciones de Tierras de aquella Jurisdiccion, y otros tres tambien interinamente la de San Juan de Teotiguacán; y el segundo Don Andrés Gil, exerció el mismo tiempo de tres años de Teniente de Alcalde Mayor del expresado Partido de Santa Maria de Tonatla [sic], y Tetela, aviendose debido a su solicitud, y cuidado el aumento de un nuevo Pueblo en la propia Jurisdiccion, y ambos desempeñaron exactamente su obligacion, dando cumplimiento a lo que fue de su cargo: como todo lo referido mas individualmente resulta de los Instrumentos, que en esta Secretaria del Consejo, y Camara de las Indias de la Negociacion de las Provincias de la Nueva España, presentó la parte, a quien se volvieron. Madrid veinte, y dos de Abril de mil, setecientos, y sesenta, y dos.

Es copia de la Original, formada el propio dia en la mencionada Secretaria de la Nueva España, donde queda. [firmado] Phelipe de Aldunate. 
3. M. MURGUÍA, "Don José Cornide y sus versos en gallego", $B R A G, \mathrm{n}^{\circ} 114$, $1^{\circ}$.II,1917, pp. 162-169, y n ${ }^{\mathrm{o}} 115,1^{\circ}$.III.1917, pp. 179-182.

No nos atrevemos a calificar de vida literaria la que irrumpió en los primeros años del siglo XVIII en Galicia, pues las guerras habían aniquilado y obscurecido tanto esta región, que pudiera considerársela como muerta. Un acentuado rasgo de prosaísmo devoraba su producción poética, de un mod tal que ya no se halla quien, en la decadencia a que había llegado, tuviese el desenfado de aquel que, clérigo o no, escribiera en defensa del Patronato del Apóstol Santiago, las inolvidables décimas llenas de gracia que empezaban:

Santo da barba dourada

Vello honrado meu patrón

que aún hemos oído cantar en las puertas de la catedral compostelana en el segundo tercio del siglo XIX, y no tuvieron igual importancia y despreocupación en todo el XVIII, en el cual puede asegurarse que al menos en su primera mitad todos nuestros versificadores "eran Fruime", tanto en gallego como en castellano.

Tras del estrecho ascetismo que dominó en España, sobre todo, en los últimos años del siglo XVII, un aire de renacimiento cino con la paz a coronar la guerra de Sucesión, renovando la sociedad hispánica, abriéndo sus ojos a nuevos horizontes, gracias a los cuales iban desvaneciéndose las anteriores inquietudes, entrando aquélla en las familias como habían entrado en el Estado.

Una nueva vida parecía afirmarse entre la gente abrumada bajo el peso de un diario infortunio y entre la herida por iguales dardos que no dejaban al mísero ni sosiego en su casa ni esperanza de mejora alguna en el mundo, pues todas sus puertas se le habían cerrado. Mas como niño que viene a la vida y al cual los padres consuelan con todo género de cariños, la nueva generación así creció también y llenó ciudades y aldeas que parecían como agotadas. Galicia a orillas de sus puertos, en medio de sus montañas, allí donde un poderoso centro de protección facilitaba la renovación de las multitudes que por donde quiera asomaban, en virtud de aquel modo avasallador que tanto satisfizo a nuestro P. Sarmiento, entendiendo que era una fecundación de la tierra y una renovación de la raza qu epoblaba nuestro suelo.

$\mathrm{Y}$ en verdad no se equivocaba, pues ciudades y campos que aun se sentían agitados, sacudidos y estrujados por los impuestos y sus agentes, abrieron sus almas al aire de fuera con que la nueva dinastía les brindaba y entraron en una animada existencia completamente diversa de la anterior. Para ellos todo había sido hasta entonces aislamiento y dolor, cuando lo que ansiaba la gente nueva era aire, esparcimiento, goce sencillo pero interesante que les ofrecían las discusiones científicas, el 
estudio de las ciencias naturales, la poesía, la música y representaciones teatrales. Así fue como en Compostela las clases superiores, sobre todo las intelectuales, se vieron envueltas en ese movimiento, que facilitó la fundación en 28 de enero de 1731, de una Academia, a la que concurrió lo más granado de la ciudad, bajo el punto de vista de la inteligencia y de la doctrina. Fue la primera y aunque duró poco, se la tomó como un ejemplo y estímulo acertado, en tal modo, que a la manera de las acosadas por las mismas ansias, las principales poblaciones gallegas respondieron con representaciones y festejos que duraban desde las últimas horas de la tarde hasta las primeras de la mañana siguiente. Y era que en todas partes se ansiaba respirar otros aires de felicidad y de alegría, vivir horas de consuelo que compensasen las de las hondas tristezas sufridas. Animábales para ello la esperanza de novedades remuneradas de cuantas sequedades y apartamientos de la vida que a todos cercaban. Por eso allí donde con motivo de una fiesta cualquiera se celebraban públicos regocijos, a los cuales se daba la mayor ostentación posible para que gozasen de ellos cuantos podían hallarlos gratos, eran amenizados con las representaciones teatrales, música y danzas, cuyos alegres rumores llegaban hasta lo más íntimodel alma popular, a la cual satisfacían los entreactos (pousos en nuestro idioma), en los cuales las composiciones satíricas en su casi totalidad, en que se manifestaban las ansias de mejoras, la necesidad dde justicia, la pública condenación de las violencias que sufría tanto el campesino como el resto de los ciudadanos.

¿Cómo extrañar que, por tales caminos, emulando los éxitos de la Academia compostelana, la inquieta gente de la milicia intentase fundar en la Coruña, un centro literario que llenase el vacío que en esta ciudad se echaba de menos? Imposible en aquellos momentos, imposible entre la oficialidad que la guarnecía, imposible bajo todos los puntos de vista que debiera considerarse el asunto, cuando se pensó en crear dentro de sus muros una "Academia de poetas", que afirmando los linderos que limitaban, las que se ofrecían a más, no quisiesen traspasarlos.

No sabemos si llegó a formarse ni siquiera se halla noticia del año en que se pensó en fundarla. Consta, y es bastante, por las obras del famoso Cura de Fruime, que el militar D. José Piñel se dirigió a él como secretario de la citada corporación, en demanda de su concurso, mas no como pudiera sospecharse, hubiese de organizarse bajo el título de "Academia de Apolo".

Los públicos festejos con que estos centros intelectuales celebraban hechos, o recordaban señaladas fechas históricas o religiosas, eran siempre importantes. En Noya, representaban anualmente los estudiantes sus comedias en honor de San Bartolomé, patrón de la villa, lo mismo que en 1773, con motivo de un sermón del arzobispo Bocanegra, y para felicitarle, las hubo también en Santiago. No con producciones teatrales, pero sí con la animación y manifestación ostentosa, coronaba 
el cabildo compostelano la octava del Corpus, en el claustro, gracias a los animados paseos de la admirable Música de Capilla, sin igual entonces en el número y mérito excepcional de los concertistas, entre todas las demás iglesias de España.

Mas hay una, entre todas las fiestas que se recuerdan celebradas en el siglo XVIII, que salvando los estrechos límites de ciudad y región, se adelantó a festejar una fecha: la del nacimiento de Carlos III, de quien habiendo tomado posesión del reino, esperaba España todo género de prosperidades. Tuvo ésta lugar en enero de 1761, en Sada, pequeña villa en la cual se hallaba instalada la Real fábrica de jarcias, a la que asistían numerosos individuos en ella empleados, y sobre los cuales recayó la realización de los festejos, a los cuales acudió lo más notable de las familias de la Coruña y Betanzos, para presenciarlas, por entender que eran dignas de la importancia oficial de quienes los celebraban.

A pesar de todo, ni noticia hubiera quedado de tan importante fiesta, a no haberse conservado copia de las décimas que, describiéndola, nos dejó nuestro D. José Cornide Saavedra, de quien ni aun conociéndose tan por extenso su vida y trabajos, pudo sospecharse hubiese escrito, ni en castellano ni en gallego.

$$
* * *
$$

Por la villa de Sada, sus alrededores y diversas viviendas que se levantaban bajo sus cielos, se extendía entonces a diario un aire de felicidad que oreaba a cuantos trabajaban en la Real fábrica de jarcias, que allí tenía establecida el Estado. Aires de bienestar y felicidad llenaban los hogares de empleados y hacían más gratas las aficiones literarias de los jefes que los dirigían, manteniendo entre todos un sentimiento de estrecha amistad con los principales señores que vivían en la hermosa aldea de Mondego. Una, la primera entre todas, la de nuestro Cornide quien ayudó a llevar a cabo la importante función con que los oficiales de dicha fábrica celebraron el primer cumpleaños de Carlos III, siendo rey de España. A ella contribuyó también nuestro paisano, describiéndola después en deécimas en gallego que tienen para nosotros el doble mérito de ser suyas y darnos una muestra de cómo entendía su tiempo que debía ser la ortografía de ciertos vocablos genuinamente gallegos, respecto de los cuales no deja de importar para esclarecer las cuestiones a que dan lugar actualmente las diferencias que se notan entre la gráfica de nuestro vocabulario y la de su hermano gemelo el portugués, pues según puede notarse, atendió la mayor parte de las veces a su etimología, al uso de la $g$, de la $j$ y de la $x$, signos ortográficos que tenniendo el mismo sonido en nuestra fonética, se diferencian tanto en su gráfica. Y así escribe Gil con $g$; o con $j$, juez, dijo, jente, ja, jonllos, 
deseja, deije, pujeron, pajaros y fijera; y con $x$, fixo. Hizo más, escribió a la portuguesa la $\tilde{n}(n h)$ en minha y enmaranhou, dándonos en la misma forma que se usa en Portugal la voz cuma (c'unha).

$* * *$

Diose principio a la fiesta con una loa, que se encargó al entonces famoso cura de Fruime, a la cual siguió un refresco ofrendado por el buen Gil, Ministro de la Maestranza. Púsose después de esto en escena una comedia de Calderón titulada "Afectos de odio y amor", que escogió para ello el mismo Gil como persona entendida en asuntos literarios, sobre quien parece recayó todo lo relativo al orden y dirección de la fiesta. En los intermedios (pousos, en gallego) tocaban los gaiteros y se representaban las momerías o entremeses que entrañaban particular interés, pues en ellos se ponían de manifiesto dolorosos trances que a cada momento sufrían los indefensos. En el primero se presentaron un escribano y un juez dispuestos a embargar cuanto hallasen a mano, y que en aquel momento extendieran su acción hasta la iglesia y su campanario, mas la justicia popular los obligó a borrar las diligencias efectuadas y marcharse con las manos vacías. En el segundo, llenó el ánimo del espectador un desvergonzado escolante, cuyo criado - el cielo sabe con qué saladas travesuras - hizo las delicias del público, que marchó en animados grupos a recorrer las calles de la población, yendo al fin a llamar a la puerta del bon vivant de Gil, que así lo dispuso tal vez, pues no sólo pretendía obsequiarles con uno de aquellos inmortales convites que entonces, y aún largo tiempo después, se usaron, sino invitando a todos a recorrer las calles de Sada y llenarlas con la alegría de sus canciones y vivas y tumultos tan de semejantes ocasiones.

Las décimas en que todo ello contó nuestro Cornide y van a continuación, no son en verdad ninguna pieza literaria digna de mayor recuerdo, aun cuando prueban hasta qué punto había llegado el prosaísmo e incorrección en esta y otras clases de composiciones, todas prosa por parte de sus autores y todo mala intención en los juicios de los que las leían. Así sucedió a Cornide, obligado despues del pecado a sufrir la condigna sentencia, defendiéndose con otras décimas y romances en gallego y castellano, en las cuales si hay algún verso cojo no dejan de abundar los prosaísmos que lo distinguen, e hicieron fáciles los ataques de que fueron objeto los siguientes versos de Cornide:

"Da quenta un Hidalgo de Polaina de aquellos mas rancios, y refinados Aldeanos a un apasionado de la Academia de Apolo, de lo que su rudeza pudo sacar a luz de una Comedia que los oficiales de la Contaduría de la Rl. Fabrica de Sada representaron el dia 20 de henero al cumpleaños de nro Rey y Sor. q.d.g. en las sig.tes 


\section{Decimas}

Ben pensarás que de Sada che bou facer relación pois ten presente que non che podo despricar nada: porque aquela enmarañada a mais da jente que tiña era jente da Mariña e non jente como queira, q'era jente de primeira e algunha tua e minha.

Que che estubo cousa boa penso que ja cho contaron e dirían que empezaron toda a festa cuma Loa: pois alí de popa a proa, eramos según barrunto todos os d'aquel conjunto q'estabamos ollo alerta coa boca tan aberta chuceiros por nosso punto.

Antes que pase d'aquí, quero decirche de paso, o millor q'en todo caso houbo q'alabar alí:

o millor por Christo sí q'é que Gil com'é o raio da franqueza e non é paio, á jente de bon vestido deu un refresco cumprido tal o de Deus ó meu saio.

Despois de ben refrescados (como digo do meu conto) fomonos a cal mais prompto uns aos outros arrimados, entramos por uns taboados que tiñan tantos mecheiros que parecían luceiros alumbrando moitos moito, e entre eles tamén escoito tocar us poucos gaiteiros.
Logo que tal vin quedei feito uma estatua dereito e dijen eu se me deito aquí quedo feito un rey: ves aquí q'a boa ley de unha probe q'alí vin tubo lastema de min, e mandoume que sentado podía estar, arrimado a ela. Meu sarafín!

Así posto desta sorte na capa repantigado cos seus jonllos apertado non che tiña medo á morte: e dixen o demo porte quen deseja mellor canto, deste modo no m'espanto que sea bo'a comedia mais que sea noite e media antes q'eu deije este canto.

Palabras non foran ditas cando os da Loa saliron, decirche que non luciron foran palabras malditas; basta que fosen escritas por Fruime as que dijeron, catro q'alí supujeron, no nome dos elementos a dar a Carlos contentos, os días que lle souperon.

Outro veu despois tamén papel do Porto facendo q'anque eu d'aquelo n'entendo parece q'o fixo ben: moitas gaitas de reten tocaban de cando en cando, e bofé que m'iban dando ben gusto cando tocaban, porque tantos chirlos daban, com'os pajaros bolando. 
Despois d'esto comezou unha comedia ou un trasno que non debeu de ser asno o que tal enmaranhou: o q'alí se relatou non ch'é facil d'expricar, solo me podo acordar dando o acordo un sudor q'afectos d'odio e amor entonces ll'oín chamar.

De un tal Caldeiron dis q'era oín a uns poucos señores e mais q'era das mellores q'o tal Caldeiron fijera q'entre todas a escollera o Contador da Mestranza, e porque n'era de chanza entre os pousos da comedia dous entremeses lle media, par'acabar cunha danza.

Despois do pouso primeiro beu no primeiro entremés, un escribano e un juez con seu papel e tenteiro: alí embargaron enteiro, podo decir, o lugar pois chegaron a embargar a igresia c'o campanario hasta q'un estrafalario todo lles fijo borrar.

O outro entremes segundo erache de un escolante pero tiñach'un vergante dun criado vagamundo este, se era inmundo e ben dado a Bercebú digo q'o digas tu, pois desde q'as apousou a todos, tamén as dou a Mestra a caron do cu.
Teño dito que da estorea mais grande, non me renembro e de falar dela tembro porque son bobo de Corea solo si fago mamorea q'os que como eu miraban todos as venias lle daban a todos e a cada un, e eu do mesmo voto fun porque todos me folgaban.

Esto posto por diante; unha Cristerna de barro q'alí andaba no carro do sol, debe ser brillante! un Turin como un diamante tamén alí se mostrou e outro q'auxiliou a Christerna ben o fijo e o que mais mal alí dijo medianamente quedou.

A baila foy regular coma todas soien ser mais despois oubo que ver ó tempo de s'acabar, s'entonces viras saltar un Domínguez no sobrado dijeras, ola! cuidado, q'este fandanguea ben pero despois beu tamén outro ben fandangueado.

Salimos por donde entramos despois d'acabado todo, sin trepar lama nin lodo á porta de Gil chegamos e se non che nos quedamos a culpa non che foy sua porque a toda canta trua saliamos da Mestranza el quería enchel a panza, e mais dar noite de rua. 


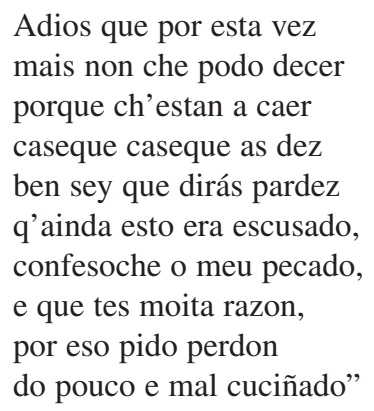

Estas décimas, aun cuando dedicadas exclusivamente a Gil con recomendación especial de que nadie las viese, anduvieron sin embargo, de mano en mano, hasta caer en las de un tal Salgado, quien las contestó con otras y un romance, disparatado y lleno de burlas e injurias, según en aquella época se acostumbraba [...].

4. Relacion de los servicios de Don Andres Gil Taboada, Teniente de Alcalde Mayor que ha sido del Partido de Santa Maria de Jonatla, y Tetela en las Provincias de la Nueva España.

Consta, que es natural de la Ciudad de la Coruña en el Reyno de Galicia, hijo legitimo, y de legitimo matrimonio de Don Joseph Gil Taboada, y de Doña Teresa del Rio, Paz, y Cordido, naturales de la Feligresía de San Nicolás de Mosteiron, en el propio Reyno; Nieto por linea paterna de Don Jacobo Gil Taboada, y de Doña Maria Pedreira de Bregondo; y por la materna de Don Raphael Paz, y Cordido, y de Doña Ana del Rio: quienes igualmente, que sus ascendientes, han sido, y son Christianos viejos, Hijos Dalgo, y de conocida Nobleza; y como tal, el nominado su Padre, obtuvo los Empleos de Administrador de las Rentas del Tabaco de la referida Ciudad de la Coruña, y su Jurisdiccion, y Visitador General, con las facultades correspondientes, de las Reales Dehesas de S. M. en el mismo Reyno, cuya familia se halla emparentada con el señor Don Phelipe Gil Taboada, Governador que fue del Real, y Supremo Consejo de Castilla, y Arzobispo de Sevilla, y con el señor Don Cayetano Gil Taboada, Arzobispo que tambien fue de Santiago en el expresado Reyno.

Que aviendo pasado a la Nueva España el mencionado Don Andres, sirvió tres años de Teniente de Alcalde Mayor del Partido de Santa Maria de Jonatla, y Tetela, en cuyo tiempo administró Justicia con toda equidad, desinterés, y aprobacion, cumpliendo exactamente con su obligacion, y zelando la satisfaccion de los Reales Intereses en el quinto de las Platas de aquel Real de Minas, y demás derechos de la 
Real Hacienda: procurando su mayor aumento en la fundacion de un nuevo Pueblo de Indios en la propia Jurisdiccion, nombrado Santa Catharina Altepeco (Alias) Tenalpulco el nuevo, distante de aquella Cabecera treinta leguas, de caminos muy asperos: al qual reduxo, y dio posesion a costa de su notorio desvelo, y en virtud de Despacho del Marqués de las Amarillas, siendo Virrey de aquellas Provincias, a muchas familias de Indios, que andaban fugitivos, sin pagar Tributo, ni oir Missa, y carecian del Pasto Espiritual, en grave daño de sus Almas, a cuyo fin se valió de todos los medios que le fueron posibles; y en la Residencia que se le tomó del referido tiempo, no resultó contra él quexa, ni demanda alguna, antes bien se verificó la estimacion que todos los Vecinos hicieron por su caridad, y ajustados procedimientos.

Y ultimamente, que sus dos hermanos Don Juan, y Don Joseph Gil Taboada, el primero se halla sirviendo a S. M. de Oficial de la clase de Segundos de la Contaduría principal de Marina del Departamento de Cadiz, y de Ministro Director de la Real Fabrica de Jarcia, Lonas, y Lanillas del Puerto de Sada; y antes obtuvo los Empleos de cadete en el Regimiento de Infantería de Granada, Escrivano de Marina, Maestre de Jarcia de la Real Armada, Contador de Navio, y de Depositario de los Caudales destinados para la enunciada fabrica, y edificios que para ella se construyeron, en los quales cumplió a satisfacción, y al presente lo está executando en los que actualmente tiene; y el segundo Don Joseph Gil, sirvió interinamente tres años la expresada Alcaldía Mayor de Santa Maria de Jonatla, y Tetela, y de Juez Subdelegado de Ventas, y Composiciones de Tierras de aquella Jurisdiccion; y por tiempo de otros tres, tambien interinamente, la de San Juan de Teotiguacan, cuyos Empleos exerció exactamente, dando cumplimiento a lo que fue de su cargo: como todo lo referido mas individualmente resulta de los Instrumentos, que en esta Secretaria del Consejo, y Camara de las Indias de la Negociacion de las Provincias de la Nueva España, presentó la parte, a quien se bolvieron. Madrid, diez, y nueve de Abril de mil, setecientos, y sesenta, y dos.

Es Copia de la Original, formada el propio dia en la mencionada Secretaria de la Nueva España, donde queda. [firmado] Pedro de la Vega

5. Relación de méritos de Don Carlos Gil Taboada y Figueroa, individuo del Ministerio de Marina.

Consta que es hijo legítimo, y de legítimo matrimonio de Don Juan Gil Taboada y Figueroa, natural del Reyno de Galicia, y de Doña Maria de la Torre y León, que lo es del de Granada, quienes, como sus Ascendientes, han sido, y son Christianos viejos, y Caballeros Hijosdalgo de notoria Nobleza, y es sobrino de los Ilus- 
trisimos Señores Don Felipe, y Don Cayetano Gil Taboada, éste Arzobispo que fue de Santiago, y aquel Gobernador del Real, y Supremo Consejo de Castilla, y Arzobispo de Sevilla.

Que el expresado Don Carlos sirvió a S. M. de meritorio en el Ministerio de Marina por espacio de diez años y dos meses: ocho años y nueve meses a mérito sin sueldo, y el un año y cinco meses restantes con él, destinado en la Contaduría Principal de Marina del Ferrol, y a otras comisiones en el Arsenal de la Graña, hasta que, por providencia de Don Joaquin de Maguna, Intendente de la misma Marina, y Departamento, se le concedió licencia ilimitada a fin de dar curso a varios negocios proprios; habiendo desempeñado los encargos que se pusieron a su cuidado, y señaladamente los de Revistador de Maestranzas, Interventor de los Asoleos de Pólvora, y fábrica de los Ornos de Reberbero, a entera satisfacción de sus Superiores, manifestando su conducta, aptitud, y vigilancia en todos los referidos destinos, considerandole acreedor a que la piedad de S. M. atienda su mérito.

Que su padre Don Juan sirvió tambien a S. M. cincuenta y dos años, nueve meses, y once días en calidad de Cadete desde once de Marzo de mil setecientos veinte y dos, hasta Julio de setecientos treinta en el Regimiento de Infanteria de Granada, hallandose de guarnicion en este intermedio en las Plazas de la Coruña, San Sebastian, y Santander, y tambien en el Sitio de Gibraltar, y Plaza de Ceuta: hizo varias campañas de Mar: fue a la expedicion de Napoles, y succesivamente se le destinó en la Armada de Barlovento: obtuvo la Administracion, y Direccion del Real Hospital de la Habana: la Intervencion general de los efectos, que condujo por S. M. y Comercio la Flota del mando del Excelentisimo Señor Don Andrés Reggio, que llegó al Ferrol el año de quarenta y nueve: corrió la posta para asegurar a la Real Hacienda veinte y ocho tejos de oro, que recogió, y entregó en la Tesorería de Marina, sin admitir gratificacion, ni sobresueldo: estableció la Real Fábrica de Jarcia, y Lonas en la Villa y Puerto de Sada; y distribuyó, durante fue Depositario en ella, tres millones, ciento ochenta y un mil setenta reales, y veinte maravedis liquidos, y manifestó como Ministro Director de dicha Fábrica su aptitud en aumento de la Real Hacienda; y finalmente fue Interventor de consumos en el Astillero, y Ministro Inspector del Real Hospital del Ferrol: Ministro de Fondeos de America, y de Viveres de la Real Armada, acreditando en todos estos encargos su mayor zelo, y amor al Real servicio, según todo mas por menor resulta de varias Certificaciones, y otros instrumentos que presentó, y bolvió a recoger la Parte.

Es copia de la Original que se formó, y queda en esta Secretaría de la Camara de Gracia, y Justicia, y Estado de Castilla. Madrid primero de Octubre de mil setecientos setenta y seis. 


\section{6. "Montevideo Junio 30 de 1802}

Mi venerada y amada Madre:

Estando en el campo y frontera de los portugueses he rrecivido la funesta noticia de la muerte de mi amado Padre que en paz descanse. Me fue muy sensible como la de mi tia y prima mas como a de ser, para este fin emos nacido, y debemos conformarnos. En la campaña que hemos tenido he pasado muchos travajos, pero ya gracias a Dios me beo con mas descanso. Mi hermano [Juan] todavia no ha venido, y si lo estoy esperando el dia 8 o 10 del mes que entra, pues se que ya viene de retirada, a su llegada pasamos a Buenos Ayres donde esta nuestra Compañía. Yo ya estubiera alla a no ser que me han concedido licencia para esperarlo, y irnos juntos. Remito a Vm el adjunto poder que $\mathrm{Vm}$ me pide, este va por mi solo, lo uno, por estar Juan ausente, y lo otro por parecerme suficiente por mi solo, a vista de el podra Vm (como me dice en la suia) hacer las demandas que combengan, solicitandolo todo por vien, pues creo que el meterse en pleitos y sin dinero es disparate, en fin, Vm haga lo que mejor le paresca, que en todo soy igual (y seré) a Vm.

He sabido que Don Miguel Quenon [¿?] está en Buenos Ayres, a quien no tengo todavia la satisfaccion de conocer pero, con motivo de mi pronta marcha a aquella, le conoceré, y estaré a la mira de lo que Vm me encarga, en la anterior del año pasado, diciendo a Vm que mejor proporcion se admita en caso de tal pensar.

Son muchos mis deseos de abrazar a Vm, como a mis hermanitos y hermanitas, pero este gusto creo lo tendré tarde, como ygualmente a mi Amigo y estimado Don José, etc.

He savido que mi Prima Antoñita está casada, o para casarse con un Marino; no se la verdad. A Pepe Maria, mi Primo, dirá Vm que me acuerdo mucho de el, pero el está tan olvidado que ni memorias me manda. No obstante esto se las dará Vm mias, como a todos los Parientes, y a mi Madrina, sin olvidarse de las Señoritas de Rivadulla, y las dará a los que se acuerden de preguntar por mi.

En el correo siguiente escrivirá Juanito, pues ahora no lo hace por lo que ddejo a $\mathrm{Vm} \mathrm{dh}{ }^{\circ}$. A mis hermanitas y herm ${ }^{\circ}$, de $\mathrm{Vm}$ mil abrazos, diciendoles que se apliquen y procuren mejor carrera que la nuestra. A mi amado Don José, sin embargo de que adjunto le escrivo dele Vm muchas espresiones, y Vm mi amada Madre, en compañía de mis hermanitos, mientras no tengo el consuelo de abrazarlos tiernamente, recivan mis finos afectos, acordandose cada ynstante de pedir a Dios Nuestro Señor este su hijo quiera darle resignacion y tolerancia para tan repetidos golpes y travajos, y la salud y satisfaccion que le desea este que es su humilde y tiernamente le ama

\section{Jose Gil de Taboada}

P. D. he recibido las quatro camisas y 2 escarapelas por las quales doy a Vm las gracias.

Amada Madre y Mi Sra D $^{\mathrm{a}}$ Juana Gil de Taboada." 
7. Manuel de CASTRO LÓPEZ, "Don José Gil y Taboada", Almanaque Gallego para 1915, Radaelli, Buenos Aires, 1914, pp. 49-51.

Parece que algunos documentos no tienen en el pormenor ninguna importancia sino para la persona a quien se refieren, y que, por consiguiente, aquella se pierde en absoluto cuando ésta y sus herederos y sucesores desaparecen del mundo; mas, por muy particualares que sean, hay asuntos que entrañan interés no despreciable en el estudio; veámoslo, sino.

En una "Relación individual de los gastos que hace la provincia de Buenos Aires en los militares y empleados", etc, Relación tirada por la imprenta de la Independencia probablemente en el año 1821 (no lleva fecha), siendo Gobernador y Capitán General don Martin Rodríguez, se lee bajo el epígrafe "Pensiones que resultan de la invasión de los ingleses", en la página 8: "Da Victoria Pestaña, viuda del cadete don José Gil Taboada ... 55 ps. 7 cs. 30 ms.”.

Es indudablemente dicho D. José el "subteniente Gil Taboada", muerto en la defensa de Montevideo, y a quien D. Pascual Ruiz Huidobro, Jefe de Escuadra y ex Gobernador de la misma plaza, tomada por los ingleses el día 3 de febrero de 1807, incluía en una lista de los individuos por él recomendados para premios, publicada en el tomo XXXIX de la Revista Nacional, de Buenos Aires.

Hijo de don Andrés Gil y Taboada y de doña Juana Gil y Taboada de la Torre, el don José había nacido en la feligresía de San Nicolás de Mosteirón (corresponde al ayuntamiento de Sada, partido judicial de Betanzos), en el reino de Galicia; y, en 22 de octubre de 1806, cuando era cadete de la cuarta compañía del Regimiento de Infantería de Buenos Aires, se casó, a la edad de veinticuatro años, en la vice parroquia de San Ignacio de esta ciudad, con la doña Victoria Pestaña, porteña e hija de don Juan Amaro Pestaña y de doña Josefa Rodríguez Cardoso: de ello fueron testigos D. José Sourrière de Souvillac ${ }^{54}$ y doña Mariana Pérez de la Mata. Así consta en el expediente número 6 del legajo 107 de la Notaría eclesiástica; a folios 486, vuelto, y 487 del libro $6^{\circ}$ de matrimonios de la parroquia de la Catedral; y en el "Suplemento y libro único Castrense de bautismos, matrimonios y muertos=Catedral al Norte". Cayó, pues, Gil Taboada en plena luna de miel.

Pero ¿basta a todo militar el morir por la Patria para ser en la posteridad recordable fuera, en su caso, de la crónica o historia de los sucesos en que intervino, si no aparece que hubiese sido uno de esos magníficos héroes que, como el genio, como el sabio y como el santo, según acertadamente pensaba Concepción Arenal, dan lustre y esplendor al espíritu humano? Entiendo que no. Voluntario o forzoso, el soldado no hace en absoluto nada de notable en cumplir su obligación; y uno de

\footnotetext{
${ }^{54}$ Este individuo había sido profesor en la Academia de Arquitectura Naval de Ferrol.
} 
esos deberes consiste en sacrificarse en aras de su bandera. Pero, como la guerra es dura, no todos tienen el valor de entregarse con franqueza y abnegación a ella: que el contraste se ofrece constantemente, cual una ley natural, en todo y en todas partes; precisamente Gil Taboada tuvo compañeros indignos de él, según lo demuestra una "Relación de los oficiales de la guarnición de la plaza de Montevideo que en su defensa no se han procedido con el honor correspondiente o no han tenido la constancia necesaria para sufrir los riesgos y la fatiga que exigía el sitio que la pusieron los enemigos el 19 de Enero del presente año ohasta el 3 de Febrero en que fue tomada por asalto": nómina autorizada por Ruiz Huidobro en Madrid a 29 de diciembre de 1807, y que dio a conocer tambien la Revista Nacional. Luego merece acariciarse la memoria de Gil Taboada, lo propio que la de cuantos, como él, son víctimas de la obligación que honrosamente contraen. Para algo más, empero que para acariciarla, he recogido algunos de los datos transcritos.

En el año 1813 aún no se había declarado la emancipación política de las Provincias del Río de la Plata; pero, desde 25 de mayo de 1810, la capital de ellas procedía como si fuese independiente. Pues bien: con fecha 4 de febrero del citado año 1813, la Soberana Asamblea General Constitutiva acordó, cual se lee en el tomo primero del Registro Oficial de la República Argentina, "que las viudas que gozan en la actualidad del Monte (pío) Militar y Político, aunque sean de los españoles europeos tienen derecho a su vez, pero que las viudas de los españoles europeos que no disfruten de este beneficio, deben ser absolutamente privadas de las pensiones que les hayan sido asignadas y hayan percibido hasta el presente, exceptuando aquellas que hayan obtenido por servicios hechos a la patria después de nuestra revolución, en cuyo caso deben continuar percibiéndolas". Proclamada la indpendencia el 16 de julio de 1816, cumplíase por el Gobierno de Buenos Aires la resolución que acabo de reproducir; lo dice, por ejemplo, la pensión que a la viuda de Gil Taboada se daba en 1821. y este hecho me hace recordar otros que, con él, me llevan a una conclusión digna de señalarse.

A partir de la revolución del antes citado día 25 de mayo, el Gobierno de Buenos Aires procede violentamente contra España, como si España fuese su enemiga natural; y, sin embargo, ¿no es verdad que él, lejos de diferenciarse del español, parece, aparte su esencial tendencia a la propia soberania, la continuación del hispano? Esta es la proposición que entiendo merecedora de no pasar inadvertida.

Por el Gobierno hispano se mandaba formar juicio de residencia, consistente en averiguar la acción de sus principales mandatarios en las colonias, cuando cesaban en el desempeño de sus cargos, para, en el caso de no haber sido correcta, castigarla; y el mismo procedimiento empleaba con los suyos la revolución de Buenos Aires. Ella internaba a los españoles de la capital a ejemplo de la orden dada en 17 
de julio de 1779 al Virrey para que hiciese alejar a los ingleses, peligrosos para la seguridad del Estado, hasta cuarenta leguas de distancia de la costa. Por Reales Cédulas eran, y lo son todavía, conocidas en España ciertas disposiciones que el Soberano firma; Cédulas se denominaba a las concesiones de premios y retiros que expedía el Gobierno independiente de Buenos Aires. Ostentaba el papel empleado por las oficinas hispánicas, impresos en la parte superior, el escudo nacional y el año para que tal papel se destinaba; asimismo tenía una parte del papel de las autoridades sucesoras de la española en Buenos Aires el escudo argentino y la expresión del año. En fin: España no abandonaba a las esposas de aquellos que habían caído en defenderla; y las Provincias Unidas del Río de la Plata reconocían como propias las pensiones que la Suprema Junta de Gobierno de España, según Real Orden expedida en Sevilla el 13 de enero de 1809 al Virrey de Buenos Aires, daba a las viudas de los militares que, cual Gil y Taboada, habían muerto en la airada penetración del inglés en la Plata. Hasta se puede demostrar que las mejoras introducidas por la gobernación de la América independiente de España, libertad de comercio, tan importante y trascendental, inclusive, habían sido iniciadas, cuando no por la de la España colonial, por españoles en las colonias establecidas.

Pero es forzoso terminar aquí con lo relativo a Gil y Taboada. El pensamiento, fruto de nuestras constantes investigaciones, que, a propósito de él se nos ha ocurrido, y que exponemos en la estrechez de indispensable resumen, es lo principal en este pequeño trabajo; y, no por mera curiosidad sino por lo útil e interesante que se nos figura, merece estudiarse detenidamente, por extenso y aparte: estudio en que dicho oficial sólo sería uno de los muchos testimonios en que basaría.

A la jurisdicción del virreinato de Buenos Aires pertenecía la ciudad montevideana; pero Montevideo, después de 25 de mayo de 1810, no fue dominado por Buenos Aires, sino desde la capitulación de 20 de junio de 1814 hasta el 25 de febrero de 1815 en 1821 era presa del portugués, como lo fue del Brasil, y, al cabo, se eleva a capital de una nueva nación. Así pues, resalta la generosidad del Estado argentino en mantener la pensión de la viuda del malogrado oficial D. José Gil y Taboada. 


\section{8. "Mi Sr ${ }^{\mathrm{a}} \mathrm{D}^{\mathrm{a}}$ Juana Gil Taboada}

Guat $^{\mathrm{a}} 3$ de Diciembre de 1807

Hermana y mui $\mathrm{Sr}^{\mathrm{a}}$ mia:

Ya considero que Vm tendrá noticia de la muerte de mi amadisimo esposo y hermano de Vm Dn Andres Gil Taboada [de la Torre] que en paz descanse, pues no dudo que $\mathrm{D}^{\mathrm{a}}$ Juana Franco de Taboada a quien tengo escrita esta noticia por tres correos consecutivos se la havrá comunicado a Vm para que en sus oraciones lo encomiende a Dios; pero si por alguna contingencia de extravio $\mathrm{Vm}$ lo ignora le hago saber que fue su fallecimiento el dia veinte y tres Mayo de ochocientos cinco: dia de la Ascension del Sr en el Castillo del Golfo, en donde estaba exerciendo funciones de primer comandante: La fiebre fue maligna y tan violenta que solo duró cinco dias, la qual le embargó los sentidos, y murió intestado: Los pocos bienes que quedaron, los he vendido todos, para pagar algunas dependiencias, que me dexó comunicadas, y con todo he dado cuenta a este Sr Capitan General, que a solicitud mia y bondad suya quedó en mi poder para que yo pudiese vender y pagar a mi arbitrio, con cuyo motivo tuve ocasión de suplicar a quatro sujetos de los mismos acredores que por caridad me hicieron la gracia de ceder cada uno algun tanto a beneficio de Vm en consideracion de ser Vm viuda, y con siete hijos, por lo que suplico a Su Divina Majestad que esta mi carta llegue a sus manos, con la qual incluyo esa libranza para el Ferrol, en donde recibirá Vm ciento y diez pesos fuertes de Dn José Ribas Torrens, que es la cantidad que me hicieron gracia los quatro acreedores y amigos de mi marido: quiera Dios lleguen a tiempo que Vm pueda disfrutarlos en compañía de los niños y niñas a quienes saludo con verdadero afecto.

Tambien aviso a Vm que tengo escritas tres cartas a mi hermano Dn Francisco Gil Taboada que se halla en Carthagena de Levante para que tome posesion del Mayorazgo o Aldea de Mostairon. Vm no se olvide de encomendar a Dios a mi esposo: que yo aunque tan mala, incesantemente pido y suplico a Su Divina Magestad, lo tenga en su santa Gloria y lo mismo hago por mi amada Madresita $\mathrm{D}^{\mathrm{a}}$ Maria de la Torre y Leon oyendoles sus Misas y mandandoselas decir.

Vm me hará el gusto de contestar esta lo mas pronto que se pueda, y no por una vez sola; sino por dos o tres correos.

Dios $n t^{o}$ Señor que la apreciable vida de Vmd y felices años. B. L. M. de Vmd esta su afectisima Hermana y $\mathrm{sg}^{\mathrm{a}} \mathrm{srv}^{\mathrm{a}}$ que le ama de corazon

Rosalia Figueroa y Taboada" 


\section{SIGLAS}
AIA = Archivo Ibero Americano
AHRG = Archivo Histórico del Reino de Galicia
$\mathrm{AMC}=$ Archivo Municipal de La Coruña
$\mathrm{BRAG}=$ Boletín de la Real Academia Gallega
BOPC = Boletín Oficial de la Provincia de La Coruña
$\mathrm{CEG}=$ Cuadernos de Estudios Gallegos
$\mathrm{CNC}=$ Colegio Notarial de La Coruña
$\mathrm{D}=$ Descubrindo 